\title{
Górnołużyccy villici w pierwszej połowie XIII wieku: włodarze, sołtysi czy wójtowie?
}

\author{
Abstract \\ Upper Lusatian villici in the $1^{\text {st }}$ half of the $13^{\text {th }}$ Century: stewards, town iudices \\ or territorial advocati?
}

The text deals with the problem of the proper interpretation of the institution of villicus, mentioned in Upper Lusatia in the $1^{\text {st }}$ half of the $13^{\text {th }}$ century. The article discusses all the hitherto attempts to identify the actual nature of the Upper Lusatian villici and proposes some new interpretations. The close relations of those villici with chartered towns (namely: Zgorzelec/Görlitz and Ostritz) and the virtual lack of royal estates around them makes it possible to state that they were not, as most scholars have claimed, royal stewards taking care of estates administered directly by the Bohemian kings (in Upper Lusatia such goods probably barely existed at all). Therefore, the most probable interpretation of the villici seems to be the one presented in 1923 by J. Bauermann, who identified them with the sculteti hereditarii of particular towns.

Key words: Upper Lusatia, Kingdom of Bohemia, local administrative structures

Słowa klucze: Górne Łużyce, Królestwo Czech, lokalne struktury zarządu

Celem niniejszego tekstu będzie zinterpretowanie oraz zaklasyfikowanie w sposób najbardziej prawdopodobny i zgodny z tenorem źródeł urzędu określanego mianem villicus występującego na terenie Górnych Łużyc ${ }^{1}$ w ramach struktury zarządu terytorialnego działającego tam w pierwszej połowie XIII wieku, pod koniec drugiego okresu rządów Przemyślidów (1158-1253). Rozstrzygnięcie tego problemu, z pozoru tylko błahego, ma $\mathrm{w}$ istocie niemałe znaczenie dla zrozumienia zasad działania i organizacji zarządu w tym szczególnym regionie, który z jednej strony przez wieki stanowił strefę przej-

1 Pojęcie Górnych Łużyc, choć nieużywane w pierwszej połowie XIII wieku, będzie w niniejszym tekście stosowane dla wygody zarówno autora, jak i Czytelnika, jako współcześnie stosowana nazwa regionu. W okresie omawianym w artykule ziemie późniejszych Górnych Łużyc, do połowy XII wieku określane mianem Milska, znane były pod nazwami ziemi budziszyńskiej (zachodnia i środkowa część kraju) oraz Zagozdu (wschodnia część kraju). 
ściową między wschodnimi marchiami Niemiec, Czechami i Śląskiem, z drugiej zaś był położony w samym środku strumienia ludzi i idei płynącego po linii zachód - wschód po transkontynentalnej magistrali łączącej Kolonię z Kijowem. Obydwie te cechy Górnych Łużyc: położenie peryferyczne względem centrów politycznych oraz centralne względem szlaków wymiany myśli i towarów, zbiegły się w sposób szczególny w pierwszej połowie XIII wieku, gdy władający wówczas tą krainą królowie Przemysł Ottokar I i Wacław I tam właśnie na niespotykaną w innych partiach swego królestwa skalę prowadzili politykę budowy władztwa przez kolonizację $e^{2}$, sięgając przy tym śmiało po wzorce organizacyjne i osadników z Niemiec ${ }^{3}$. Zarówno chronologia wskazanych zjawisk (sam początek XIII wieku), jak i geograficzna pozycja Górnych Łużyc nie pozostawiają przy tym wątpliwości, że zastosowane tam rozwiązania organizacyjne mogły mieć zasadniczy wpływ nie tylko na późniejszy kształt społeczny i ustrojowy tego regionu, lecz także na rozwiązania w dziedzinie organizacji zarządu terytorialnego przyjmowane przez tych samych władców w Czechach lub na Morawach oraz przez Piastów linii wrocławskiej na Śląsku.

Główną rolę w przebudowie podstaw władzy politycznej i ekonomicznej, jaką prowadzili królowie niemieccy, aspirujący do stanowiska samodzielnych władców terytorialnych książęta niemieccy oraz władcy krajów sąsiadujących z Niemcami od wschodu, odgrywali urzędnicy sprawujący jurysdykcję z ich ramienia i zarządzający dochodami panujących w terenie: wójtowie, włodarze oraz sołtysi. Niewielka liczba źródeł z omawianej epoki oraz chwiejność używanej w nich terminologii, a także nawarstwienie się nowych zjawisk na wcześniejsze struktury, sprawiają przy tym, że w wielu przypadkach jednoznaczne zaklasyfikowanie urzędników wymienianych w źródłach pod daną nazwą łacińską napotyka znaczne trudności. Największe problemy wywołuje w tym kontekście określenie villicus, obejmujące w źródłach XII-XIV wieku całe spektrum urzędów i funkcji silniej lub słabiej związanych z głównym znaczeniem tego terminu, oznaczającego od czasów starożytnych lokalnego funkcjonariusza zarządu gospodarczego ${ }^{4}$. Już w ramach organizacji grodowej bądź kasztelańskiej monarszy villicus ${ }^{5}$ mógł występować w dwóch głównych rolach: jako jej funkcjonariusz bądź jako zarządca dóbr przeznaczonych do bezpośredniego użytku panującego, wyjętych spod jurysdykcji urzędników

2 Pojęcie to wprowadził w swej opartej na materiałach górnołużyckich, niestety nigdy nieopublikowanej rozprawie doktorskiej Max Jänecke, Die oberlausitzer Herrschaften, Spezielle und allgemeine Probleme aus ihrer Geschichte und historischen Geographie, Leipzig 1923 (doktorat napisany pod kierunkiem R. Kötzschkego, rps w bibliotece uniwersyteckiej Albertina w Lipsku, s. 223); w polskim piśmiennictwie upowszechnił je Sławomir Gawlas, O kształt zjednoczonego Królestwa. Niemieckie władztwo terytorialne a geneza spoleczno-ustrojowej odrębności Polski, Res humanae: Studia, t. 1, Warszawa 1996 (wyd. 2, 2000). W sposób sugestywny, choć niewątpliwie przesadzony, na wcześniejsze niż w Czechach i na Śląsku wprowadzenie nowych standardów organizacyjnych na Górnych Łużycach zwrócił uwagę Walter Jecht, Neue Untersuchungen zur Gründungsgeschichte der Stadt Görlitz und zur Entstehung des Städtewesens in der Oberlausitz, „Neues Lausitzisches Magazin” (dalej: NLM) 1919, Bd. 22, s. 60.

3 Por. H. Helbig, Die Oberlausitz im 13. Jahrhundert. Herrschaften und Zuwanderung des Adels, „Jahrbuch für die Geschichte Mittel- und Ostdeutschlands” 1956, Bd. 3, s. 59-127.

4 Por. instruktywne zestawienie możliwych znaczeń tego określenia u Josefa Žemlički, Kasteláni, vilikové a beneficia $v$ netransformované transformaci, „Český Časopis Historický” 2008, t. 106, nr 1, s. 121-123, szczególnie przyp. 40 na s. 122, oraz dalsze uwagi w niniejszym tekście.

5 Pomijam tu problem włodarzy działających z ramienia możnowładców bądź urzędników monarszych, również spotykanych w źródłach z tego okresu. 
grodowych $^{6}$. Terminy villicus i villicatio zyskały też nowe znaczenia w miarę rozwoju akcji immunitetowej i lokacyjnej, będąc używane, jako synonimy określeń advocatus/ advocatia i scultetus/scultetia, na określenie wójtów (miejskich i terytorialnych, tak zwanych landwójtów) lub sołtysów działających w ramach lokacyjnych wspólnot miejskich i wiejskich?

W odniesieniu do Górnych Łużyc można w zasadzie wykluczyć jedynie ewentualności, że tutejsi villici z pierwszej połowy XIII wieku funkcjonowali w ramach organizacji grodowej bądź kasztelańskiej przede wszystkim ze względu na ich dość jednoznaczne powiązanie z miastami lokacyjnymi wschodniej części kraju (o czym szerzej w dalszej części niniejszego tekstu) oraz brak w źródłach jakiejkolwiek wzmianki o tak nazywanych urzędnikach budziszyńskich - a tylko w Budziszynie znajdowała się siedziba kasztelana (burgrafa) ${ }^{8}$. Hipotezy oparte na wszystkich pozostałych możliwościach - tożsamości górnołużyckich villicorum z królewskimi włodarzami (w rozumieniu urzędników zarządzających własnością panującego), wójtami bądź sołtysami - pojawiły się w dotychczasowym piśmiennictwie, choć zwykle marginesowo, przy okazji omawiania innych zagadnień 9 . Zanim jednak zostaną one szerzej przedstawione i skomentowane, warto przyjrzeć się bliżej dotyczącym górnołużyckich villicorum wzmiankom źródłowym.

\section{Villici w źródłach: Floryn ze Zgorzelca (1223-1234)}

Górnołużyccy funkcjonariusze zarządu terytorialnego - villici - byli wzmiankowani w pięciu dokumentach z okresu drugich rządów Przemyślidów w regionie (1158-1253).

${ }^{6}$ O obydwu funkcjach włodarzy monarszych zob. K. Modzelewski, Włodarz [w:] Stownik Starożytności Slowiańskich, t. 6, Wrocław 1977-1980, s. 527-528; idem, Organizacja gospodarcza państwa piastowskiego X-XIII wiek, PTPN: Wznowienia, t. 7, Poznań 2000 (wyd. 1, Warszawa 1975), s. 98-99, passim. Na Śląsku w roli włodarzy w drugim z podanych znaczeń występowali klucznicy, a w Małopolsce: komornicy.

7 Zob. niżej, przyp. 42, 48-49; por. też H. Eberhardt, Die Gerichtsorganisation der Landgrafschaft Thüringen im Mittelalter, ZRg GA 75: 1958, s. 177; L. Jan, Vzník zemského soudu a správa středověké Moravy, Brno 2000, s. 45-46. Użycie terminu villicus na określenie wójta lub sołtysa jest zasadne, ponieważ urzędnicy ci oprócz przewodniczenia własnym sądom określonych społeczności reprezentowali wobec nich zwierzchność dominialna, pełniąc tym samym niejako pewne funkcje włodarskie (por. J. Bauermann, Die ältesten Urkunden für Kloster St. Marienthal aus den Jahren 1234-1245, NLM 1923, Bd. 99, s. 122-123, przyp. 5).

8 Por. analogiczne opinie R. Jechta, Geschichte von Görlitz bis um die Mitte des 13. Jahrhunderts, NLM 1894, Bd. 70, s. 234, oraz J. Bauermanna, Die ältesten Urkunden ..., s. 122. W odniesieniu do Zgorzelca brak, oprócz późnej i anachronicznej wzmianki Dubraviusa o tutejszym prefekcie (Johanni Dubravii Olomuzensis Episcopi Historia Bohemica, Frankfurt 1687, s. 308), jakichkolwiek źródłowych śladów istnienia kasztelanii; należy domniemywać, że ośrodek ten od 1158 roku był zarządzany z Budziszyna.

9 Odsyłacze do odnośnych tekstów znajdzie Czytelnik poniżej, szczególnie w częściach 4-7 niniejszego artykułu. Zasadnicze znaczenie dla omawianych tu zagadnień mają opracowania Hermanna Knothego (Urkundliche Grundlagen zu einer Rechtsgeschichte der Oberlausitz von ältester Zeit bis zur Mitte des 16. Jahrhunderts, NLM 1877, Bd. 53, s. 161421), Waltera Jechta (Neue Untersuchungen..., przyp. 2), Johannesa Bauermanna (Die ältesten Urkunden..., przyp. 7), Wilhelma Weizsäckera (Zur Geschichte des Zittauer Landgerichts, NLM 1934, Bd. 110, s. 1-22) i Rudolfa Kötzschkego (Vogtei und Weichbild in der Oberlausitz [w:] idem, Deutsche und Slawen im mitteldeutschen Osten: Ausgewählte Aufsätze, ed. W. Schlesinger, Bad Homburg 1961, s. 150-169 - pierwodruk w: Oberlausitzer Beiträge. Festschrift für Richard Jecht, ed. F. Pietsch, Görlitz 1938, s. 16-33). 
Dwa najstarsze z nich dotyczą urzędnika ściśle powiązanego z lokowanym w początkach XIII wieku Zgorzelcem, imieniem Floryn. Po raz pierwszy wystapił on jako Florinus de Gorlez wśród komisarzy przeprowadzających rozgraniczenie dóbr królewskich i biskupich na Górnych Łużycach przed 1228 rokiem (najprawdopodobniej w roku 1223) ${ }^{10}$. Po raz kolejny, tym razem jako Florinus villicus de Gorliz, ten sam Floryn pojawił się w 1234 roku, obok między innymi wójta (advocatus) Wolframa, jako świadek na dokumencie królowej Kunegundy dla domu klasztornego Marienthal ${ }^{11}$.

Choć pozycja Floryna na obydwu listach świadków nie pozostawia wątpliwości co do jego szlacheckiej kondycji, Richardowi Jechtowi udało się zidentyfikować jego prawdopodobnych potomków wśród zgorzeleckiego patrycjatu ${ }^{12}$. Wystapienie Floryna około 1223 roku wśród komisarzy granicznych, którzy wedle tego dokumentu już wcześniej uniformiter burquardos terrarum distinxerunt, przemawia przy tym za przypuszczeniem, że był on uznawany za eksperta nie tylko w sprawach związanych z obszarem podległym jurysdykcji miasta Zgorzelca, lecz także w odniesieniu do otaczających ten ośrodek terenów wiejskich ${ }^{13}$. Znamienny jest też długi okres urzędowania Floryna (co najmniej 11 lat) oraz jego współwystapienie na liście świadków z urzędnikiem explicite określonym jako wójt. Wszystkie te okoliczności okażą się niewątpliwie pomocne we właściwym zaklasyfikowaniu pełnionego przez Floryna urzędu.

\section{Villici w źródłach: przywileje dla zgromadzenia Marienthal $z$ lat $1238-1239$}

Kolejne wzmianki dotyczące górnołużyckich urzędników określanych jako villici pochodzą z dwóch przywilejów króla Wacława I dla fundowanego przez jego żonę Kunegundę zgromadzenia cysterskiego Marienthal nad Nysą z lat 1238-1239 $9^{14}$. W dokumentach tych zawarta jest libertacja posiadłości owego domu zakonnego od jurysdykcji królewskich urzędników określonych jako advocati, villicii oraz nuntii. Zostały tam także wy-

10 Dokument nie zachował się w formie osobnego dyplomu, lecz w postaci listy komisarzy i protokołów dokonanego przez nich opisu bądź ujazdu granic, wpisanych do tzw. Górnołużyckiego Dokumentu Granicznego (niem. Oberlausitzer Grenzurkunde) z 1241 roku (Codex diplomaticus nec non epistolaris Regni Bohemiae, Praha 1904, ed. G. Friedrich - dalej cyt. jako CDB - IV/1, 4). O procesie powstawania i datowaniu poszczególnych partii tego dyplomu por. R. Jecht, Neues zur Oberlausitzer Grenzurkunde, NLM 1919, Bd. 95, s. 68-73.

11 CDB III, 86.

12 Pozwoliło na to jego rzadkie imię: R. Jecht, Geschichte der Stadt Görlitz, t. I/1: Allgemeine Geschichte der Stadt Görlitz im Mittelalter, Görlitz 1926, s. 27.

13 Por. R. Kötzschke, Vogtei..., s. 160. O udziale Floryna w kolonizacji wiejskiej okolic Zgorzelca może świadczyć pierwotna nazwa dzisiejszej Żarskiej Wsi: Florinsdorf (późn. Florsdorf), szczególnie że położenie tej miejscowości sugeruje jej wczesną lokację i już w połowie XIV w. pozostawała ona w rękach zgorzeleckich mieszczan; por. H. Knothe, Geschichte des Oberlausitzer Adels und seiner Güter, Leipzig 1879, s. 611; K. Czok, Zur Entwicklung der Oberlausitzer Sechsstädte vom 13. Jahrhundert bis zur Gründung ihres Sechstädtebundes 1346 [w:] Beiträge zum spätmittelalterlichen Städtewesen, ed. B. Diestelkamp, Städteforschung: Veröffentlichungen des Instituts für vergleichende Stadtgeschichte in Münster, ed. H. Stoob, Reihe A, Bd. 12, Köln-Wien 1982, s. 113.

14 CDB III, 176, 207. 
mienione miasta, w których rezydować mieli królewscy wójtowie (advocati), a mianowicie: Budziszyn, Zgorzelec, Löbau, Reichenbach i Weissenberg ${ }^{15}$.

Większość badaczy do dziś bierze zawarte w przytoczonych dyplomatach dane dotyczące zestawu urzędów na Górnych Łużycach za dobrą monetę ${ }^{16}$, mimo że już w 1923 roku Johannes Bauermann wysunął przeciw nim silne argumenty wynikające z dogłębnej analizy dyplomatycznej owych dokumentów. Badacz ten nie tylko stwierdził jednoznacznie, że obydwa przywileje wykazują dyktat odbiorcy, lecz także wskazał miejsca, w których ściśle powtarzają one sformułowania zawarte w dyplomach margrabiów miśnieńskich dla zgromadzenia cysterskiego Altzelle. Wśród tych zapożyczonych fragmentów, odpisanych zapewne przez współpracującego z cysterkami marienthalskimi mnicha z Altzelle z przywilejów jego macierzystego domu zakonnego, znajdują się także te dotyczące górnołużyckich wójtów i włodarzy ${ }^{17}$. Wniosek ten skłonił Bauermanna do wykreślenia owych przywilejów z listy źródeł opisujących rzeczywistość ustrojową górnołużyckich posiadłości Przemyślidów u schyłku lat 30. XIII wieku.

Do wyników badań tego autora ze znaczną dozą ostrożności odnieśli się Richard Jecht, Wilhelm Weizsäcker i Rudolf Kötzschke ${ }^{18}$. Szczególnie ten ostatni słusznie wskazał na konieczność zniuansowania wniosków Bauermanna, podnosząc, że dokumenty te nie mogły całkowicie abstrahować od realiów kraju, którego dotyczyły. Niemniej, w związku ze ścisłą zależnością dokumentów marienthalskich z lat 1238-1239 od przywilejów dla Altzelle, logicznie prawomocne jest jedynie stwierdzenie, że zawarta w nich lista urzędników królewskich nie pozostawała w wyraźnej sprzeczności z rzeczywistymi stosunkami panującymi wówczas na Górnych Łużycach, nie sposób jednak głosić na podstawie tych źródeł poglądu, że odzwierciedlały one ściśle struktury zarządu terytorialnego istniejące nad Nysą i Sprewą. Bardziej już wiarygodna od listy urzędów zapożyczonej z dokumentów dla Altzelle jest przytoczona w dyplomatach lista miast królewskich, w których mieli rezydować urzędnicy obdarzeni władzą sądzenia, choć z przytoczonego wyżej powodu ich klasyfikacja jako (land)wójtów nie powinna następować automatycznie i uchodzić za bezsporną ${ }^{19}$.

\section{Villici w źródłach: Henryk, villicus Ostritz}

Ostatnia wzmianka o urzędniku nazwanym villicus z czasów panowania Wacława I datowana jest na rok 1241 i pochodzi z dokumentu poświadczającego kontrakt kupna-

15 Ta lista miast koresponduje z położeniem marienthalskich posiadłości, już wówczas rozrzuconych wokół samego klasztoru i dalej na północy, na zachód od Zgorzelca (por. R. Kötzschke, Vogtei..., s. 160). Jest wprawdzie wysoce prawdopodobne, że w momencie wystawiania dyplomów cysterskich marienthalskie nie miały jeszcze dóbr w bezpośredniej okolicy wszystkich wskazanych ośrodków (co w przypadku Budziszyna nie jest koniecznie, gdyż tam z pewnością rezydował wójt krajowy, iudex provincialis), w dokumentach tych zaznaczono jednak wprost, że chodzi o dobra, które vel nunc habent, vel habiturae sint.

16 Por. niżej, przyp. 24-26.

17 J. Bauermann, Die ältesten Urkunden..., s. 121-125.

18 R. Jecht, Geschichte der Stadt Görlitz..., t. I/1, s. 33, przyp. 6; W. Weizsäcker, Zur Geschichte..., s. 4-5; R. Kötzschke, Vogtei..., s. 160.

19 Por. niżej, w ustępie 7. „Interpretacja II: villici jako sołtysi miejscy”. 
-sprzedaży zawarty przez zgromadzenie Marienthal z niejakim Henrykiem i jego brać$\mathrm{mi}^{20}$. Przedmiotem transakcji była wieś Seifridsdorf, obecnie opuszczona, usytuowana w bezpośrednim sąsiedztwie Marienthalu ${ }^{21}$. Mniszki zapłaciły za przejęcie własności wsi 80 grzywien srebra Henrykowi villico in Ostrose[n] (czyli w pobliskim miasteczku Ostritz) oraz jego braciom Rudolfowi i Hartmanowi, a także 40 grzywien Henrykowi von Dohna tytułem bliżej nieokreślonych praw w przedmiotowej miejscowości, na których posiadanie ten się powoływał.

Niestety w dokumencie nie określono, na jakie konkretnie prawa mógł się powołać w Seifridsdorfie syn burgrafa Ottona von Dohna. Nie ulega jednak wątpliwości, że cała włość Ostritz, rozciagająca się wokół Marienthalu po obu stronach Nysy, w późniejszym okresie należała do tej właśnie rodziny ${ }^{22}$. Równocześnie jednak villicus Henryk, sprzedając cysterkom Seifridsdorf, powoływał się na otrzymanie go w lenno wprost od króla ${ }^{23}$. Próba wyjaśnienia tej niejednoznaczności zostanie podjęta $\mathrm{w}$ dalszej części niniejszego tekstu. Wcześniej jednak należy się Czytelnikowi krótki przegląd przedstawionych dotychczas w piśmiennictwie prób interpretacji górnołużyckiego urzędu z pierwszej połowy XIII wieku, określanego mianem villicus.

\section{Interpretacja I: villici jako włodarze}

Przegląd ten zacząc wypada od pierwszej nowoczesnej syntezy dziejów prawa i ustroju Górnych Łużyc w średniowieczu autorstwa jednego z najwybitniejszych luminarzy miejscowej historiografii, Hermanna Knothego ${ }^{24}$. Jest to tym bardziej uzasadnione,

20 CDB IV, 9 (=Codex Diplomaticus Lusatiae Superioris, Bd. I, ed. G. Köhler, Görlitz 1858, 37).

21 Cena aż 120 grzywien, jaką zapłaciły mniszki za ową miejscowość, wskazuje przy tym, że chodziło o nabycie całej wsi, a nie jej części bądź tylko dominium directum; por. J. Bauermann, Die ältesten Urkunden..., s. 119; J. Prochno, Regesten zur Geschichte der Stadt und des Landes Zittau 1234-1437, NLM 1937, Bd. 113, s. 81, 87 (3, 7); H. Helbig, Die Oberlausitz ..., s. 82-84. Odmienną opinię wygłosił niedawno L.-A. Dannenberg (Das Kloster St. Marienthal und die Burggrafen von Dohna. Überlegungen zur Gründung des Zisterzienserinnenklosters an der Neiße, NLM, Neue Folge 2008, Bd. 11, s. 100-102), nie zbijając jednak głównych argumentów przemawiających za nabyciem Seifridsdorfu nad Nysą przez zgromadzenie dopiero w 1241 roku, czyli obecności tylko jednej wsi o podobnej nazwie w wykazach dóbr zgromadzenia powstałych przed tą datą (gdzie wyliczona została ona z innymi tzw. Dolnymi Wsiami, co sugeruje jej tożsamość z miejscowością później zwaną Nieder-Seifesdorf, obecnie w Gemeinde Waldhufen, Landkreis Görlitz) oraz wysoka cena nabywanych wówczas praw.

22 Por. H. Knothe, Die Burgrafen von Dohna auf Grafenstein, „Archiv für Sächsische Landesgeschichte, Neue Folge" 1875, Bd. 1, s. 201-204; idem, Geschichte des Oberlausitzer Adels..., s. 660-663; por. też ostatnio: L.-A. Dannenberg, Ostritz - früstädtische Entwicklungslinien einer oberlausitzischen Kleinstadt, NLM Neue Folge 2006, Bd. 9, s. 183-184; idem, Das Kloster..., s. 193.

23 CDB IV, nr 9: Nos igitur villam pretaxatam in manus nostras a prefatis fratribus resignatam siquidem eam a nobis in pheudo habuerunt, coenobio $S$. Marie [...] contulimus perpetuo possidendam. Na sprzeczność między istnieniem w tym okresie włości Ostritz w posiadaniu Doninów oraz villici zależnego wprost od króla zwrócił uwage już W. Jecht, Neue Untersuchungen..., s. 44, przyp. 9.

24 Urkundliche Grundlagen..., s. 172-181; por. także idem, Zur älteren Geschichte der Stadt Bautzen bis zum Jahre 1346, „Neues Archiv für die Sächsische Geschichte” 1884, Bd. 5, s. 83-86. O do dziś aktualnym znaczeniu pierwszego z przywołanych opracowań Knothego por. S. Gawlas, $O$ ksztalt..., s. 165, przyp. 652, oraz N. Kersken, Zur Rechtsgeschichte/Verfassungsgeschichte der Oberlausitz [w:] Oberlausitz:

Artykuły - Articles 
że twierdzenia przedstawione przez tego autora zostały podtrzymane przez tak wielu późniejszych badaczy ${ }^{25}$, iż współcześnie można uznać tę interpretację za dominująca w historiografii ${ }^{26}$.

Zaprezentowana przez Knothego wizja organizacji zarządu terytorialnego na Górnych Łużycach za Przemysła Ottokara I i Wacława I opiera się przede wszystkim na literalnym potraktowaniu omówionych już powyżej dokumentów dla Marienthalu z lat 1238-1239. Zakłada ona zatem istnienie w owym czasie, obok funkcjonującego od połowy XII wieku urzędu burgrafa (kasztelana) budziszyńskiego, dwuinstancyjnej struktury sprawujących sądownictwo wyższe landwójtów (których siedzibami były królewskie miasta) z wójtem budziszyńskim na czele ${ }^{27}$ oraz osobnego od niej pionu zarządzającego dobrami należącymi do domeny monarszej, którego funkcjonariuszami mieli być właśnie villici, czyli włodarze ${ }^{28}$.

Znaczna liczba późniejszych badaczy przejęła koncepcję Knothego w całej rozciagłości, nie starając się jej sprecyzować ani uzupełnić. W tym kontekście warta wspomnienia jest jedynie sugestia Richarda Jechta, który, odnalazłszy prawdopodobnych potomków najstarszego znanego villici zgorzeleckiego Floryna wśród patrycjuszy miasta, wysunął przypuszczenie, że już w pierwszej połowie XIII wieku urząd włodarski w Zgorzelcu nie był osobno obsadzany, lecz przekazany w lenno jednemu z mieszczan ${ }^{29}$.

Beiträge zur Landesgeschichte. Wissenschaftliches Symposium zum 100. Todestag von Hermann Knothe, ed. M. Herrmann, D. Weber, Görlitz-Zittau 2004, s. 47-64.

25 R. Jecht, Geschichte von Görlitz..., s. 247; W. Jecht, Neue Untersuchungen ..., s. 14, 59; R. Doehler, Diplomatarium Vallis S. Mariae monasterii sanctimonialium ord. cist. (Die Urkunden des Königlichen Jungfrauenstifts und Klosters Zisterzienser-Ordens zu St. Marienthal), NLM 1902, Bd. 78, s. 11 (szczególnie przyp. 4), 15; M. Reuther, Verfassung und Verwaltung in der Oberlausitz bis zur Beginn des Sechsstädtebundes 1346 [w:] Oberlausitzer Forschungen: Beiträge zur Landesgeschichte, ed. M. Reuther, Leipzig 1961, s. 82-83, 86; K. Czok, Zur Entwicklung..., s. 110; idem, Die Kleinstädte im Oberlausitzer Sechstädtebund [w:] Hansische Stadtgeschichte - Brandenburgische Landesgeschichte, ed. E. Engel, K. Fritze, J. Schildhauer, Hansische Studien VIII, Weimar 1989, s. 126.

26 Tak też zostały potraktowane w najnowszych pracach traktujących o ustroju Górnych Łużyc w czasach Przemyślidów: S. Gawlas, $O$ ksztatt ..., s. 52 (tu jednak z wyraźnym zastrzeżeniem, że źródła nie pozwalają na pewną rekonstrukcję struktur zarządu); G.E. Schrage, Die Oberlausitz bis zum Jahr 1346 [w:] Geschichte der Oberlausitz, ed. J. Bahlcke, Leipzig 2001, s. 69, 75. Interpretacja górnołużyckich villicorum jako włodarzy została także przyjęta przez piszacego niniejsze słowa w pracy popularnonaukowej: Vademecum historii Górnych Łużyc, Lubań 2010, s. 49 oraz atlasie multimedialnym dołączonym do książki.

${ }_{27}$ O dwustopniowej strukturze wójtostw pisali wprost: H. Knothe, Urkundengrundlagen..., s. 179; E.-H. Lemper, Burgberg und Neißeübergang: Bemerkungen zur bistorischen Jopographie von Görlitz [w:] Landesgeschichte als Herausforderung und Programm: Karlheinz Blaschke zum 70. Geburtstag, hrsgb. U. John, J. Metzrath, Leipzig-Stuttgard 1997, s. 111; G.E. Schrage, Die Oberlausitz ..., s. 69. Swej akceptacji dla tego twierdzenia nie wysłowił explicite M. Reuther, na podstawie przesłanek pośrednich można jednak wnosić, że autor ten akceptował także tę tezę Knothego (M. Reuther, Verfassung..., s. 86, passim). Por. także W. Jecht, Neue Untersuchungen..., s. 59.

28 H. Knothe, Urkundliche Grundlagen ..., s. 174-175.

29 R. Jecht, Geschichte von Görlitz..., s. 247. Pomysł przekazania zgorzeleckiego włodarstwa Florynowi akurat w lenno nie został przez cytowanego autora w żaden sposób uzasadniony. 


\section{Interpretacja Ia: villici jako włodarze oraz rozwój włodarstw w landwójtostwa}

Pewną korektę do „klasycznej” koncepcji Knothego wprowadził Walter Jecht, sugerując, że królewscy włodarze (villici) nie tylko działali równolegle do struktury landwójtostw ${ }^{30}$, lecz także dali jej samej początek. Tak przynajmniej można rozumieć twierdzenie tego badacza, że u zarania swych rządów Wacław I zastapił włodarstwa (klucze królewskich dóbr) wójtostwami, czyli okręgami sądowej zwierzchności rezydujących w miastach królewskich landwójtów ${ }^{31}$. Walter Jecht skrytykował także twierdzenie Knothego, jakoby królewskim wójtom w miastach towarzyszyli sołtysi dziedziczni poszczególnych miejscowości, postulując wprowadzenie sołtystw dziedzicznych ${ }^{32} \mathrm{w}$ miastach dopiero pod panowaniem askańskim, w miejsce zlikwidowanych landwójtostw ${ }^{33}$.

Podobnie jak W. Jecht, powstanie górnołużyckich landwójtostw z kluczy dóbr monarszych (villicationes) przyjął w swej monografii średniowiecznych dziejów miasta Zgorzelca (Görlitz) jego najwybitniejszy dziejopis, Richard Jecht ${ }^{34}$. Walter i Richard Jechtowie zasugerowali się przy tym właśnie przykładem Zgorzelca, gdzie w latach 1223-1234 występował villicus Floryn, po czym już w 1238 roku miasto to zostało wymienione jako siedziba jednego z królewskich wójtów (advocati). Za przykładem wspomnianych badaczy podążył także w swej monografii dotyczącej ustroju i zarządu terytorialnego na Górnych Łużycach do 1346 roku Martin Reuther, według którego villicus zgorzelecki Floryn był jednym z górnołużyckich landwójtów „okręgowych” (Bezirksrichter), a późniejsze miejskie dystrykty (weichbildy) rozwinęły się z istniejących w XIII wieku włodarstw (villicationes) ${ }^{35}$. W ostatnich latach powstanie na Górnych Łużycach landwójtostw obdarzonych uprawnieniami w zakresie sądownictwa wyższego z królewskich włodarstw przyjął także Lars-Arne Dannenberg ${ }^{36}$.

Najsłabsze punkty koncepcji W. Jechta i kontynuatorów stanowia postulowane w niej: dziedziczny charakter domniemanych landwójtostw oraz ich rzekome kompetencje sądownicze in maioribus. Założenia te zmuszają do przyjęcia, że na początku rządów askańskich nastapiła gruntowna reforma zarządu terytorialnego Górnych Łużyc polegająca na zniesieniu landwójtostw, skupieniu sądownictwa wyższego w rękach wójta krajowego oraz wprowadzeniu w miastach królewskich instytucji sołtysów dziedzicznych.

30 W. Jecht, Neue Untersuchungen ..., s. 59.

31 Ibidem, s. 45-46, 52, 58.

32 W niniejszym tekście na określenie urzędu sołtysa miejskiego i powiązanej z nim wiązki uprawnień używam archaicznego dziś nieco terminu „,sołtystwo” jako mniej obciążonego współczesnymi konotacjami niż używany do dziś w praktyce administracyjnej termin „sołectwo”.

33 Ibidem, s. 58-59. Por. podobne opinie K. Czoka, Zur Entwicklung..., s. 110; idem, Die Kleinstädte..., s. 126; por. także G.E. Schrage, Die Oberlausitz..., s. 82, gdzie epoce askańskiej przypisano jedynie wprowadzenie tytułu sołtysa miejskiego, lecz nie (o ile można zorientować się z oszczędnych sformułowań autorki) samej funkcji.

34 R. Jecht, Geschichte der Stadt Görlitz..., s. 27, 33. Tezy przedstawione w tej pracy znamionują pewną ewolucję stanowiska R. Jechta w porównaniu z jego wcześniejszym, cytowanym wyżej, opracowaniem, zapewne pod wpływem studium W. Jechta.

35 M. Reuther, Verfassung..., s. 82-83.

36 L.-A. Dannenberg, Ostritz ..., s. 184, przyp. 39; idem, Das Kloster..., s. 101.

Artykuły - Articles 
Nawet jeśli sołtysami poszczególnych miast stawaliby się po prostu automatycznie ich aktualni landwójtowie, to i tak panujący musieliby wcześniej skupić ich uprawnienia w zakresie sądownictwa wyższego. Reforma ta musiałaby zostać przeprowadzona bardzo szybko, gdyż dowodnie już w 1261 roku zwierzchnią jurysdykcję we wschodniej części kraju sprawował wójt krajowy budziszyński ${ }^{37}$, oraz nie pozostawić najmniejszych śladów w źródłach, co wydaje się mało prawdopodobne.

Te i inne mankamenty koncepcji W. Jechta zostały dostrzeżone i wytknięte już przez Johannesa Bauermanna ${ }^{38}$. Akceptując uwagi krytyczne tego badacza, dowodzącego w sposób przekonujący nieistnienia na Górnych Łużycach landwójtostw obdarzonych kompetencjami sądowniczymi in maioribus, obronę zasadniczych tez Waltera Jechta podjął Wilhelm Weizsäcker ${ }^{39}$. Autor ten wskazał nie bez racji, że argumenty Bauermanna wymierzone przeciw domniemanym landwójtostwom górnołużyckim nie przeczą w zasadzie ani istnieniu samych wójtów okręgowych, tyle że niesprawujących jurysdykcji in maioribus ${ }^{40}$, ani możliwości powstania landwójtostw z królewskich włodarstw. To ostatnie twierdzenie wynika $z$ ogólniejszego poglądu tego badacza przekonanego o bezpośrednim związku genetycznym włodarzy grodowych z wójtami/sędziami krajowymi (iudices provinciales, Landrichter), dającym się według niego wykazać dla Moraw w XIII wieku ${ }^{41}$.

\section{Interpretacja Ib (Rudolfa Kötzschkego): villici jako włodarze-landwójtowie}

Nieco odmiennie na temat górnołużyckich włodarstw i wójtostw wypowiedział się Rudolf Kötzschke. W przeciwieństwie do Waltera Jechta, a zgodnie z sugestią Weizsäckera, zrezygnował on z ostrego przeciwstawiania sobie pojęć villicatio i advocatia, na przykładach miśnieńskich i czeskich wskazując na ich wymienne używanie w źródłach ${ }^{42}$.

37 Wójt krajowy Gerard wystapił wówczas jako iudex territorii w sprawie dotyczącej Dittersbachu auf dem Eigen (H. Knothe, Urkundliche Geschichte des Eigenschen Kreises, NLM 1870, Bd. 47, aneks źródłowy, nr 1). Dopiero w 1268 roku w związku z podziałem kraju na dzielnice wydzielono osobne wójtostwo krajowe zgorzeleckie.

38 J. Bauermann, Die ältesten Urkunden..., s. 121-122, passim.

39 W. Weizsäcker, Zur Geschichte..., s. 4-5.

40 Byliby oni wówczas tożsami z sołtysami miejskimi, por. ibidem, s. 4. Do sprawy tej powrócę w dalszych partiach opracowania.

41 Ibidem, s. 5. Badacz ten nawiązał do wcześniejszych tez R. Kossa. Ostatnio pomysł rozwoju morawskich wójtostw krajowych $\mathrm{z}$ włodarstw głównych grodów morawskich księstw dzielnicowych odświeżył L. Jan, Vzník..., s. 42-54, wywołując ożywioną dyskusję w piśmiennictwie czeskim.

42 R. Kötzschke, Vogtei..., s. 157-159; o wymiennym stosowaniu pojęć villicatio i advocatia por. także: W. Weizsäcker, Zur Geschichte..., s. 4; W. Schlesinger, Zur Gerichtsverfassung des Markengebiets östlich der Saale im Zeitalter der deutschen Ostsiedlung, ,Jahrbuch für die Geschichte Mittel- und Ostdeutschlands” 1953, Bd. 2, s. 57, przyp. 1. Szczególnie trafne jest wskazanie przez Kötzschkego i Weizsäckera na wymienność określeń villicatio i advocatia w dokumencie lokacyjnym Uničova z 1223 roku (CDB II, 246), błędnie (w duchu zastapienia włodarstw przez wójtostwa) zinterpretowanym przez W. Jechta, Neue Untersuchungen..., s. 23-24, 58. 
Jednocześnie autor ten podkreślił wyższą rangę wójtów (advocati) niż włodarzy (villici), dostrzegając też przypadki rozwoju miśnieńskich włodarstw w wójtostwa ${ }^{43}$.

Ostatecznie Kötzschke wstrzymał się z jednoznaczną interpretacją villicorum górnołużyckich, zakreślając jedynie na podstawie własnej, dogłębnej znajomości stosunków w Saksonii, dopuszczalne pola interpretacji obejmujące zarówno „włodarskie” (tj. gospodarcze), jak i „,wójtowskie” (scil. sądowe) uprawnienia owych urzędników. Głównej odmienności koncepcji Kötzschkego od propozycji przedstawianych przez innych badaczy skłonnych uznać villicos za landwójtów należy upatrywać w konsekwentnej rezygnacji z przeciwstawiania włodarstw (związanych z organizacją aparatu państwowego poprzedzająca wielką akcję immunitetową i kolonizacyjna) wójtostwom, jako instytucji związanej z tymi właśnie zjawiskami ${ }^{44}$.

\section{Interpretacja II: villici jako sołtysi miejscy}

W kierunku całkowicie odmiennym niż reszta badaczy podążył w swych badaniach Johannes Bauermann. Zagadnienie górnołużyckich villicorum poruszył on wprawdzie jedynie na marginesie źródłoznawczego studium dotyczącego najstarszych dokumentów marienthalskich, przytoczone jednak przezeń w lapidarnej formie argumenty zasługują ze wszech miar na uwagę. Jak wspomniano już wcześniej, badacz ten wykazał ścisłą zależność dokumentów królewskich dla Marienthalu z lat 1238-1239 od podobnych dyplomów margrabiowskich dla zgromadzenia Altzelle i w związku z tym postulował, by nie traktować ich jako źródła do rekonstrukcji struktury zarządu terytorialnego Górnych Łużyc ${ }^{45}$. Przyjmując na podstawie dokumentu z 1234 roku, na którym świadkowali i wójt Wolfram, i villicus Floryn współistnienie na Górnych Łużycach urzędników o wyższych (advocati) i niższych (villici) kompetencjach sądowych, autor ten zauważył jednak trzeźwo, że nie ma w tym układzie miejsca na (mniejsza o to, czy wywodzące się z włodarstw, czy nie) królewskie wójtostwa obdarzone wyższym sądownictwem ${ }^{46}$. Dalsze szczegóły argumentacji wspierającej tę tezę, skądinąd dość przekonujące, nie są najistotniejsze z punktu widzenia interpretacji urzędników określanych mianem villici. Pierwszorzędne znaczenie przypisać natomiast trzeba konstatacji Bauermanna, że skoro owi villici nie mogli być wójtami okręgowymi (bo tacy po prostu nie istnieli), to byli oni najpewniej tożsami z dziedzicznymi sołtysami królewskich miast.

Autor ten nie dostrzegł niestety, że aby jego dedukcyjny wniosek o tożsamości villicorum z sołtysami miejskimi mógł być uznany za prawomocny, powinno się wyeliminować jako mniej prawdopodobne wszystkie alternatywne interpretacje, czyli także tradycyjną koncepcję Knothego uznającą tych urzędników za włodarzy dóbr królewskich. Co więcej, nie wskazał, dlaczego sołtysi miejscy mieliby być wymienieni w kontekście immunitetu sądowego dóbr Marienthalu, składających się przecież z posiadłości wiejskich,

43 R. Kötzschke, Vogtei..., s. 158.

${ }^{44}$ Podobne postawienie problemu można znaleźć zreszta już w pracy Ernsta Alwina Seeligera, Geschichte der Stadt Löbau und ihrer Umgebung bis zur Mitte des 13. Jahrhunderts, NLM 1921, 97, s. 126-127.

45 J. Bauermann, Die ältesten Urkunden..., s. 122.

46 Ibidem, s. 124. 
zadowalając się w tej mierze przypuszczeniem, że sformułowania dotyczące jurysdykcji królewskich urzędników zostały mechanicznie i bezmyślnie (recht gedankenlos) przejęte do konceptów przywilejów marienthalskich ze stanowiących wzór dokumentów dla Altzelle.

\section{Interpretacje I i II jako podstawy dalszej analizy}

Mimo wskazanych mankamentów koncepcji Bauermanna nie sposób zaprzeczyć, że zaproponowane przezeń utożsamienie villicorum z sołtysami miejskimi pozwala spójnie logicznie wyjaśnić zupełny brak przed 1253 rokiem jakichkolwiek wzmianek zarówno o dziedzicznych sołtysach miejskich, jak i o wójtach rezydujących w którymkolwiek mieście górnołużyckim innym niż Budziszyn ${ }^{47}$. Zastrzeżeń nie budzi przy tym użycie określenia villicus dla nazwania sołtysa, gdyż rzeczywiście zdarzało się to $\mathrm{w}$ wiekach XII-XIV zarówno w odniesieniu do sołtysów wiejskich ${ }^{48}$, jak i miejskich - w tym drugim przypadku na ziemiach Rzeszy ${ }^{49}$, a także na obszarach rozwijającej się kolonizacji

47 Nie licząc oczywiście feralnych przywilejów dla Marienthalu z końca lat 30. XIII wieku.

48 Dla terenów „starej” Rzeszy zob. na przykład Urkundenbuch der Stadt Friedberg, ed. G. von der Ropp, Bd. 1, ed. M. Foltz, Marburg 1904, 90; Hessisches Urkundenbuch, Abt. 1: Urkundenbuch der Deutschordens-Ballei Hessen, Bd. 1, ed. A. von Wyss, Publikationen aus den königlich Preußischen Archiven 3, Leipzig 1879, 105; dla obecnej Saksonii: Codex Diplomaticus Saxoniae Regiae (ed. E.G. von Gersdorf, Leipzig 1864-, dalej cyt.: CDS), II 1, 53; CDS II 4, 399 (przez G.E. Schrage, Die Oberlausitz ..., s. 94, przyp. 60, raczej niesłusznie występujący w źródle villicus de Chrobere zinterpretowany jako włodarz); dla Śląska: Schlesisches Urkundenbuch (ed. H. Appelt, W. Irgang, Köln-Graz 1978-, dalej cyt.: SUB), III, 48, 59; SUB IV, 152, 290; SUB VI, 319 orazLiber fundationis claustri Sancte Marie Virginis in Heinrichow, czyli Księga Henrykowska, przeł. R. Grodecki, wyd.2, red. J. Pater et al., ks. I, rozdz. IX, s. 139, 145; dla Czech: CDB IV, 103; CDB V/1, 352; CDB V/2, 500, 577 oraz dalsze przykłady przytoczone przez J. Žemličkę, Kasteláni...; dla terenów położonych na północ od Górnych Łużyc: Codex Diplomaticus Brandenburgensis, ed. A. F. Riedel, Bd. I, Berlin 1838, 233; Kodeks Dyplomatyczny Wielkopolski, Poznań 1877-(dalej cyt.: KDW), II, 729; Pommersches Urkundenbuch, Bd. II, ed. R. Prümers, Köln 1970, 975; Pommerellisches Urkundenbuch, ed. M. Perlbach, Danzig 1882, 353; F. Bertheau, Die geschichtliche Entwicklung der ländlichen Verhältnisse im Fürstentum Ratzeburg, ,Jahrbücher des Vereins für Mecklenburgische Geschichte und Altertumskunde” 1914, Bd. 79, s. 93-94 (tu bardzo ciekawy przykład wystapienia i sołtysa = villicus, i włodarza); L. Enders, Siedlung und Herrschaft in Grenzgebieten der Mark und Pommerns seit dem zweiten Hälfte der 12. bis zum Beginn des 14. Jh. am Beispiel der Uckermark, „Jahrbuch für Wirtschaftsgeschichte” 1987, 2 , s. 106. Por. też: H. Krug, Untersuchungen zum Amt des „,centenarius”-Schultheiß. II Teil, ZRG GA 1971, Bd. 88, s. 97, przyp. 49; H. von Loesch, rec.: G. E. Müller, Stühle und Distrikte als Unterteilungen der SiebenbürgischDeutschen Nationaluniversität 1141-1876: Verfassungsrechtliche Forschungen, Schriftenreihe der Deutschen Volksgruppe in Rumänien, Herrmannstadt 1941, ZRG GA 1943, Bd. 63, s. 442.

49 Zob. przykłady przytoczone przez J. Bauermanna, Die ältesten Urkunden..., s. 122-123, przyp. 5. Por. też: Ausgewählte Urkunden zur Erläuterung der Verfassungsgeschichte Deutschlands im Mittelalter: Zum Handgebrauch für Juristen und Historiker, ed. von W. Altmann, E. Bernheim, Berlin 1891, 50; Codex diplomaticus monofrancofurtanus. Urkundenbuch der Reichsstadt Frankfurt, ed. J. F. Boehmer, Bd. I, ed. F. von Lau, 159; Würtembergisches Urkundenbuch, Bd. VII, Stuttgart 1900, 2376; Bd. VIII, Stuttgart 1903, 3223, 3375; Quellen zur Rechts- und Wirtschaftsgeschichte der rheinischen Städte: Bergische Städte I: Siegburg, oprac. F. Lau, Bonn 1907, Publikationen der Gesellschaft für Rheinische Geschichtskunde, t. 29, s. 27; H. Krug, Untersuchungen..., s. 97; M. Buhlmann, Kaiserswerth und die ezzonischen Pfalzgrafen (= Beiträge zur Geschichte Kaiserswerths, Reihe Mittelalter, H. 5), Düsseldorf-Kaiserswerth 2008 (http://www.michael-buhlmann.de/PDF_Texte/mbhp_bgkw05_pdf.pdf, s. [6] dostęp: 1. 2012).

Artykuły - Articles 
w krajach Europy Środkowo-Wschodniej ${ }^{50}$. Z perspektywy niniejszego studium szczególnie znamienne wydaje się wystapienie oboczności villicatio/advocatia w dokumencie lokacyjnym Uničova z 1223 roku, a także prawdopodobna tożsamość urzędników nazywanych w XIII wieku villicus i iudex (a w jednej późnej kopii XIII-wiecznego dokumentu także Schösser) w nieodległym od Górnych Łużyc Dreźnie ${ }^{51}$. Trudno także nie zgodzić się z twierdzeniem przywołanego autora, że wobec sąsiedztwa zgorzeleckiego villici Floryna z wójtem Wolframem na jednej liście świadków nieuzasadnione jest wywodzenie z instytucji villicorum domniemanych wójtostw okręgowych obdarzonych kompetencjami w zakresie sądownictwa wyższego.

Przyjmując słuszność tego twierdzenia, należy tym dokładniej przyjrzeć się dwóm jedynym spośród przedstawionych powyżej hipotez, które pozostaja z nim w zgodzie, zakładającym tożsamość górnołużyckich villicorum z włodarzami zarządzającymi dobrami domeny monarszej (Knothe i kontynuatorzy) bądź z sołtysami dziedzicznymi królewskich miast (Bauermann). Mimo niewielkiej liczby źródeł oświetlających te zagadnienia wydaje się przy tym wskazane uzyskanie przez ich analizę dodatkowych przesłanek, które mogłyby rzutować na większe lub mniejsze prawdopodobieństwo którejś ze wskazanych koncepcji.

\section{Królewskie posiadłości wokół Zgorzelca i sposób zarządzania nimi}

Przyjęcie koncepcji Knothego i epigonów (villici $=$ włodarze) zmusza do założenia istnienia w XIII wieku we wschodniej partii późniejszych Górnych Łużyc kompleksów

${ }_{50}$ Zob. przykłady przytoczone przez J. Žemličkę, Kasteláni... Określenie sołtysa miejskiego terminem villicus szczególnie upowszechniło się w Królestwie Węgier, zob. np. Codex diplomaticus Hungariae ecclesiasticus ac civilis, ed. Gy. Fejér, Buda 1829-1844 (dalej cyt: CDHung) IV/1, s. 132, 305, 314, 327, 349, 455-456; CDHung VI/1, s. 105; CDHung VII/4, s. 84; CDHung VIII/4, nr 45, 186, 204; por. tu także R. Varsik, Zo slovenského stredoveku: Výber historických štúdií a článkov z rokov 1946-1968, Bratislava 1972 , s. 233, 277, 297. Interesującego przykładu obocznego używania terminów villicus i scultetus dostarczają także źródła wspominające najdawniejszego sołtysa krakowskiego Piotra, zwykle interpretowane zresztą w duchu sprawowania przez tego samego człowieka dwóch kolejnych urzędów (por. dyskusję tego problemu przez J. Wyrozumskiego [w:] Dzieje Krakowa, red. J. Bieniarzówna, J.M. Małecki, t. I: Kraków do schyłki wieków średnich, Kraków 1992, s. 154, oraz J. Rajmana, Kraków: Zespót osadniczy, proces lokacji, mieszczanie do roku 1333, Kraków 2004, s. 173-175, idem, Krakowska civitas soltysów Piotra i Salomona [w:] Spoteczeństwo Polski średniowiecznej: Zbiór studiów, t. 12, red. S. Górzyński, Warszawa 2012, s. 52-53, tam dalsze odsyłacze).

51 Zob. CDS II 5, 1, 4, 5, 14 i por. komentarze O. Richtera, Verfassungsgeschichte der Stadt Dresden, Dresden 1885, s. 64, oraz R. Jechta, Geschichte der Stadt Görlitz..., I/1, s. 48, przyp. 9, a także: Geschichte der Stadt Dresden: Von den Anfängen bis zum Ende des Dreissigjährigen Krieges, red. Karlheinz Blaschke, Stuttgart 2005, s. 186. Trzeba przy tym mieć na uwadze, że urzędnik ten mógł być tożsamy z margrabiowskim landwójtem sprawującym jurysdykcję także poza obszarem miasta (tak jednoznacznie H. Butte, Geschichte Dresdens bis zur Reformationszeit, Mitteldeutsche Forschungen 54, Köln, Graz 1967, s. 61), przy czym jeśli przyjąć zaproponowane przez Richtera tłumaczenie określenia Schösser z późnej kopii dokumentu (CDS II 5, 5) jako villicus, a użyte w tymże źródle pojęcie Weichbild rozumieć jako zasięg jurysdykcji miejskiej, należy niewątpliwie uznać owego urzędnika, gdzie indziej wzmiankowanego jako iudex, za tożsamego z sołtysem miejskim.

Artykuły - Articles 
dóbr pozostających w bezpośrednim władaniu królów czeskich (bądź przynajmniej zakresu uprawnień dominialnych, wymagających stworzenia osobnego, zarządzającego nim aparatu), które były zawiadywane przez królewskich włodarzy ${ }^{52}$. Problem jednak w tym, że trudno na Górnych Łużycach zidentyfikować odpowiednio rozległe monarsze posiadłości, które wymagałyby osobnej administracji, a nie mogłyby być zarządzane czy to za pośrednictwem budziszyńskich wójtów krajowych (jak dowodnie działo się to później, od czasów askańskich aż po XVIII wiek), czy też (jak w posiadłościach Wettynów miśnieńskich i Piastów śląskich) przez strukturę landwójtostw w królewskich miastach (jeśli takowe rzeczywiście na Górnych Łużycach istniały), czy wreszcie poprzez wypuszczenie królewszczyzn w lenno.

Zarówno Hermann Knothe, jak i Walter i Richard Jechtowie, pisząc o domenie monarszej na Górnych Łużycach, byli w stanie wskazać jedynie na większe kompleksy leśne ${ }^{53}$. Na poparcie domniemania o jej większym pierwotnie zasięgu przytacza się także nazwy terenowe i miejscowe typu Königshain, Königsteich, Königsmühle, Königswald ${ }^{54}$. Wiadomo jednak, że w wiekach XIV-XVIII bezpośrednie posiadłości monarsze na Górnych Łużycach były nieliczne i w całości zarządzane przez oficjalistów landwójtowskich, a nie osobnych włodarzy, większość dóbr ziemskich była natomiast przekazana w lenno możnowładcom, rycerzom i mieszczanom. Powstaje zatem pytanie: czy wobec braku jednoznacznych wskazówek źródłowych na istnienie rozległych dominiów monarszych niewypuszczonych w lenno nie należałoby korzeni znanego z późnego średniowiecza systemu zarządu poszukiwać w czasach przemyślidzkich, a może nawet dawniej?

Odnosząc się do szczególnie nas interesującego subregionu zgorzeleckiego, warto nadmienić, że już w najstarszej wzmiance o Zgorzelcu, pochodzącej z 1071 roku, miejscowość ta (wówczas osada wiejska) była wymieniona nie jako dominium podlegające bezpośrednio królewskiej władzy, lecz jako skonfiskowane niejakiemu Ozerowi lenno ${ }^{55}$. O tym, że także w okresie drugich rządów przemyślidzkich pewne podzgorzeleckie dobra monarsze były zarządzane przez królewskich lenników, a nie włodarzy, świadczą losy górującego wówczas nad tą okolicą zamku wznoszącego się na wzgórzu o znamiennej nazwie Landeskrone oraz piszącej się z niego od 1225 roku rodziny rycerskiej. Wbrew opinii Hermanna Knothego ${ }^{56}$ rodzina ta, choć jej członkowie związani byli

52 Tak explicite G.E. Schrage, Die Oberlausitz..., s. 69.

53 H. Knothe, Urkundliche Grundlagen, s. 175; W. Jecht, Neue Untersuchungen..., s. 59; R. Jecht, Geschichte der Stadt Görlitz..., t. I/1, s. 17. Nie wiadomo jednak, dlaczego owymi lasami mieliby zarządzać villici, a nie, jak można by się spodziewać, forestarii. Warto przy tym nadmienić, że funkcja leśniczego, forestarius, została dla Górnych Łużyc poświadczona już w 1307 roku: H. Knothe, Urkundliche Geschichte, NLM 1870, Bd. 47, aneks źródłowy, nr 15.

54 H. Knothe, Urkundliche Grundlagen..., s. 176; M. Jänecke, Die oberlausitzer Herrschaften..., s. 161-162; H. Helbig, Die Oberlausitz..., s. 66-67; J. Zdichynec, Klášter Marienthal mezi králi, městy a šlechtou [w:] Korunní země v dějinách českého státu, cz. I: Integračni a partikulární rysy českého státuv pozdním středověku, ed. L. Bobková, Praha 2003, s. 195, przyp. 145. Nazwy te w największym skupieniu występują wokół Budziszyna, a część z nich nie ma raczej związku z bezpośrednią własnością królewską, lecz z władzą terytorialną monarchów (tak w przypadku Działoszyna - dawn. niem. Königshain - niegdysiejszej włości Ostritz, położonego na styku dominiów królewskiego i biskupiego; por. tu M. Jänecke, Die oberlausitzer Herrschaften..., s. 193).

55 CDS II 1, 31.

56 Geschichte des Oberlausitzer Adels..., s. 328-329. 
z Landeskrone aż do XV wieku, dzierżyła ów zamek jedynie za rządów Przemyślidów; już w dokumencie z 1268 roku, ustalającym zasady podziału Górnych Łużyc między linie salzwedelską i stendalską Askańczyków, zamek Landeskrone występuje bowiem jako posiadłość margrabiowska ${ }^{57}$. W związku z tym nie sposób zakwalifikować dóbr Landeskrone jako zwykłego lenna rycerskiego ani tym bardziej jako jednego z górnołużyckich władztw ${ }^{58}$. Poszukując możliwej podstawy prawnej dzierżenia owego zamku przez piszącą się zeń rodzinę, należy raczej liczyć się z formą stosunku lennego zapewniającą silną pozycję seniorowi (np. Handlehn) bądź ze związkiem danego lenna z określonym stanowiskiem urzędowym wasala (tzw. Amtslehn) ${ }^{59}$.

Casus Landeskrone jest o tyle ważny, że w sposób niedwuznaczny wskazuje, w jaki sposób Przemyślidzi w praktyce zarządzali kompleksami własnych dóbr we wschodniej części Górnych Łużyc, i że sposobem tym było wypuszczanie ich w lenno. Domysł ten potwierdza dodatkowo przypadek włości rothenburskiej, która także w 1268 roku została wymieniona jako królewska, choć jeszcze cztery lata wcześniej wystapił w charakterze świadka w pewnym zgorzeleckim dokumencie niejaki Krystian z Rothenburga ${ }^{60}$. Można oczywiście argumentować, że nawet po wyłączeniu dóbr Landeskrone ${ }^{61}$ wokół Zgorzelca pozostało dość posiadłości królewskich, by dla ich zarządu uruchomić osobny pion administracyjny w postaci włodarstwa. Czy jednak było tak rzeczywiście?

Przede wszystkim należy pamiętać, że w czasach przemyślidzkich dominium królewskie sięgało znacznie bliżej na południe niż w okresie askańskim, gdyż dobra sulikowskie pozostawały wówczas pod zwierzchnią władzą nie królów czeskich, lecz biskupów Miśni. Fakt ten, wprost wynikający z tenoru dokumentu wystawionego przez

57 Codex Diplomaticus Lusatiae Superioris, Bd. I, ed. G. Köhler, Görlitz 1858 (dalej cyt.: CDLS I), 58: Item ad civitatem Gorliz ponimus civitatem Luban, Schonenberg, Rothenberg, castrum Landischrone et dimidium Hoyerswerde cum novis et antiquis bonis tam liberis quam non liberis; por. M. Jänecke, Die oberlausitzer Herrschaften ..., s. 41-43; H. Helbig, Die Oberlausitz ..., s. 76-77.

58 Władztwami (niem. Herrschaften) określa się w górnołużyckiej historiografii wielkie posiadłości lenne należące do możnych panów, o statusie prawnym wyższym niż zwykłe lenna rycerskie; por. H. Knothe, Urkundliche Grundlagen..., s. 176-177; M. Reuther, Verfassung..., s. 84.

${ }_{59}$ H. Helbig zasugerował, że w przypadku panów von Landeskrone mogło chodzić o ich status budziszyńskich lenników zamkowych (burgmanów) (Die Oberlausitz..., s. 77); przypuszczenie to jest najlepsza jak dotąd próbą zinterpretowania podstaw prawnych dzierżenia zamku Landeskrone przez wskazaną rodzinę rycerska. Przemawia za nim zarówno fundacja Krystiana Długiego z Landeskrone dla budziszyńskiej kaplicy zamkowej pw. św. Jerzego z 1225 roku, jak i posiadanie przezeń dóbr we wsi Burk, gdzie uposażeni byli także inni manowie zamkowi (por. CDLS I, 17; poprawniejsza edycja źródła z właściwą datą: G. Köhler, Capella sancti Georgii in claustro Budesinensi, NLM, 1859, Bd. 35, s. 345-346).

${ }^{60}$ Lista świadków dokumentu zachowała się jedynie w XVI-wiecznym odpisie autorstwa Bartłomieja Scultetusa w tzw. Kürbuch Sculteti, BUWr., Akc. 1947/5, p. 93, fol. 45r: Testes sunt: Dns Wilhelmus Lübecensis ecclesiae episcopus, Bernhardus jun. de Camenz, Dns Hanko de Lisna, Gerhardus aduocatus noster, Christianus Scultetus in Gōrlitz, Scaslaus de Penzk, Christianus de Rothenburg Et filii sui, Conradus de grunenberg, Ulricus de Croghe. Por. M. Jänecke, Die oberlausitzer Herrschaften..., s. 40-41; H. Helbig, Die Oberlausitz..., s. 77-78. Część badaczy była przeciwnego zdania, widząc w Krystianie przodka znanych od XIV wieku panów na Rothenburgu (tak m.in. H. Knothe, Geschichte des Oberlausitzer Adels, s. 456), przeciw czemu przemawia jednak wyraźnie tenor dokumentu poświadczającego podział kraju przeprowadzony w 1268 roku, brak Krystiana wśród wymienionych w tym akcie wielkich wasali oraz jego pozycja liście świadków dokumentu z 1264 roku.

${ }_{61}$ W XIV-XV wieku obejmowały one zaledwie kilka wsi, zob. H. Knothe, Geschichte des Oberlausitzer Adels..., s. 624; M. Jänecke, Die oberlausitzer Herrschaften ..., s. 162, nie wiadomo jednak, w jakim stopniu sytuacja ta odzwierciedla stan sprzed 1253 roku.

Artykuły - Articles 
biskupa Henryka w Sulikowie w 1234 roku $^{62}$, został jak dotąd dostrzeżony przez niewielu badaczy ${ }^{63}$, z których żaden nie wyciagnął z niego dalszych konsekwencji i nie pokusił się o rekonstrukcję północnego zasięgu owych dóbr. Zasięg ten powinien być niewątpliwie tożsamy z początkowym przebiegiem linii granicznej opisanej w tak zwanym Górnołużyckim Dokumencie Granicznym z 1241 roku, w jego części określanej jako protokół Ia (contra Poloniam) ${ }^{64}$. Nie miejsce tu, by próbować szczegółowej rekonstrukcji owego odcinka granicznego, trzeba jednak wskazać, że granice parafii oraz nazwy miejscowe i terenowe ${ }^{65}$ wskazuja, iż północna granica dominium biskupiego przebiegała niemal pod samym Zgorzelcem, na południe od Koźmina, Tylic i Gozdanina.

Domniemane włodarstwo zgorzeleckie nie mogło także sięgać daleko na północ i północny wschód od miasta, gdzie na linii Krauscha - Deschka - Dłużyna - Strzelno rozciagało się już władztwo panów von Penzig ${ }^{66}$. Od południa przylegały do niego tereny zasiedlone i dzierżone przez rodziny możnowładcze i rycerskie Kamenzów, Schreibersdorfów, Gersdorfów i Kiesslingów ${ }^{67}$, z Gronowem, Pokrzywnikiem, Sławnikowicami i Białogórzem. Także na południowy zachód od Zgorzelca bezpośrednia władza monarsza nie mogła sięgać daleko, skoro już w 1242 roku zgromadzenie marienthalskie nabywało miejscowości Jauernick i Beheimsdorf nie od króla Wacława, lecz od rycerza Hartwiga von Dehsa ${ }^{68}$.

Zarysowany powyżej zasięg dóbr - na pewno w czasach Przemysła Ottokara I i Wacława I nienależących do monarchy (dobra pieńskie i sulikowskie), zarządzanych osobno od miasta Zgorzelca (dobra Landeskrone) oraz z pewnością (Jauernick, Behaimsdorf) lub dużym prawdopodobieństwem (dobra sławnikowickie i okoliczne) wypuszczonych w lenno - pozostawia niewielką przestrzeń, na której istnieć mogło domniemane królewskie włodarstwo zgorzeleckie. Oprócz podmiejskich folwarków obszar ten obejmowałby zaledwie około 20 wsi, a w praktyce zapewne mniej, jeśli zważyć, że w jego obrębie znajdowały się także Gersdorf, Żarki i Koźlice, z których pisali się poświadczeni od drugiej połowy XIII lub przełomu XIII/XIV wieku rycerze ${ }^{69}$, a część tego obszaru położona na północny zachód od miasta mogła być zarządzana wraz z włością zamkową Landeskrone. Jest przy tym znamienne, że o ile na podstawie źródeł XIV-wiecznych można stwierdzić istnienie na tym obszarze pewnych kompleksów lennych

62 CDS II 1, nr 117.

63 E.A. Seeliger, Die Geschichte des Friedländischen, Teil 2: Die Geschichte des Friedländischen bis zum Ausbruch des dreißigjährigen Krieges, Heimatkunde des Bezirkes Friedland in Böhmen III/2, Friedland 1926, s. 44-45; J. Huth, Die Burgwarde der Oberlausitz, „Lětopis, Reihe B: Geschichte” 1981, Bd. 28, s. 158-159; G.E. Schrage, Die Oberlausitz..., s. 73.

${ }_{64}$ CDB IV, nr 4: A Niza contra Poloniam per directum usque ad montem Yezwinche. Abinde in Cumulos Kamenicopkidua. Inde in angulum Nakuthypozchaki. Inde in Montem Tyzow. Ten sam fragment granicy dóbr biskupich jest wymieniany jako rubież dóbr sulikowskich w przytoczonym już wyżej dokumencie biskupa Henryka (CDS II 1, nr 117): inter limites, que vulgariter Jeswiken et Duekamnegorke et Tyzowe nuncupantur.

${ }_{65}$ Mianowicie: miejscowość Osiek, obecnie Deutsch-Ossig i Osiek Łużycki, góra Pfaff-Berg, obecnie Pop, w Studniskach, wzgórze Hutberg, obecnie Pastwa, w Nowej Karczmie, oraz wieś Pfaffendorf, obecnie Rudzica. Dokładniejszą rekonstrukcję przebiegu owej linii granicznej spróbuję przeprowadzić w osobnym studium.

66 Por. H. Knothe, Geschichte des Oberlausitzer Adels..., s. 569-570.

${ }_{67}$ Por. ibidem, s. 612-613; H. Helbig, Die Oberlausitz ..., s. 105-107.

68 CDB IV, nr 2.

69 Por. Knothe, Geschichte des Oberlausitzer Adels..., s. 186, 503, 611, 617, 625-626. 
dóbr rycerskich, o tyle jedyną posiadłością należącą do władcy, wchodzącą w skład uposażenia landwójtostwa, były wówczas Przesieczany ${ }^{70}$.

Zwraca oczywiście uwagę, że rodzin rycerskich piszących się z miejscowości znajdujących się w tak zarysowanym obszarze podzgorzeleckim było podejrzanie mało, nieproporcjonalnie wiele znajdujących się tu miejscowości dzierżyli natomiast zgorzeleccy mieszczanie. Mogłoby to przemawiać za długim pozostawaniem tutejszych dóbr w bezpośredniej władzy królewskiej i wypuszczeniem ich w lenno dopiero po ekonomicznym okrzepnięciu zgorzeleckiego mieszczaństwa. Warto jednak zaznaczyć, że wśród mieszczan Zgorzelca nie brakowało osób kondycji rycerskiej, zdolnych do obejmowania dóbr na prawie lennym ${ }^{71}$. Nie można więc wykluczyć, że posiadanie przez zgorzeleckich mieszczan znacznej części znajdujących się pod miastem dóbr ziemskich nie było sytuacją późną i ekstraordynaryjna, lecz sięgało czasów przemyślidzkich.

O tym, że dobra położone pod samym Zgorzelcem już w pierwszej połowie XIII wieku nie należały bezpośrednio do tamtejszego domniemanego włodarstwa, świadczy fundowanie zgorzeleckiego konwentu franciszkanów około 1234 roku - wówczas jeszcze ante opidum - na terenie gospodarstwa podarowanego przez rodzinę von Wirsing ${ }^{72}$. Folwark ów nie był raczej, wbrew użytemu w źródle określeniu (alodium) ${ }^{73}$, posiadany prawem alodialnym, lecz lennym, niemniej w źródłach nie ma mowy o jakimkolwiek związku tegoż z rzekomym gospodarstwem własnym monarchy i włodarzem, który miałby nim zawiadywać już w XII wieku ${ }^{74}$. Także po przeciwnej, wschodniej, stronie miasta lokacyjnego, dobra panującego były już około połowy XIII wieku dzierżone przez lenników. Poucza o tym wzmianka źródłowa z 1264 roku dotycząca przekazania szpitalowi Świętego Ducha przy moście przez Nysę ośmiu łanów gruntu położonych zapewne nad samą Nysa (na terenie dzisiejszego polskiego miasta Zgorzelec) ${ }^{75}$ przez niejakiego Konrada, syna Peregryna ${ }^{76}$. Dokument poświadcza konsens władzy gruntowej na tę darowiznę, niedwuznacznie stwierdzając, że przedmiotowe grunta trzymał darczyńca jako lenno. Innym świadectwem wczesnego wypuszczenia w lenno dóbr położonych pod samym Zgorzelcem jest wystapienie na liście świadków pewnego doku-

70 Por. ibidem, s. 612. Także w tym wypadku jednak trudno stwierdzić, czy nie była to aby posiadłość rycerska przejęta dopiero w XIV-XV wieku prawem kaduka. Jest w ogóle znamienne, że znaczniejszą liczbę posiadłości ziemskich dzierżyli landwójtowie górnołużyccy jedynie w ziemi budziszyńskiej; zob. Über das landvogteiliche Rentamt in Budissin, „Lausizische Monatsschrift” 1799, 2, s. 542-543.

71 Por. R. Jecht, Geschichte der Stadt Görlitz..., t. I/1, s. 27-30.

72 Annales Franciscanorum [w:] Scriptores rerum Lusaticarum, NF, t. 1, Görlitz 1839, s. 311: Anno Domini $M^{\circ} C^{\circ} X X X I I I I^{\circ}$ conventus Gorliczensis fuit fundatus per marchionem brandenburgensem et lusaciensem ante opidum, et nobiles dicti wirsynge dederunt fratribus allodium suum pro area; por. W. Jecht, Neue Untersuchungen..., s. 20; R. Jecht, Geschichte der Stadt Görlitz..., t. I/1, s. 16, 31, 34.

73 Przyjmuje się, że na Górnych Łużycach dóbr alodialnych nie było wcale (H. Knothe, Urkundliche Grundlagen..., s. 169) bądź prawie wcale (zob. R. Doehler, Diplomatarium..., s. 28, przyp. 1), a termin alodium oznaczał po prostu gospodarstwo dworskie, także dzierżone prawem lennym.

74 W. Jecht, Neue Untersuchungen..., s. 21-22, passim; R. Jecht, Geschichte der Stadt Görlitz..., t. I/1, S. $15-17,25$.

75 Por. R. Jecht, Geschichte der Stadt Görlitz..., t. I/1, s. 27.

76 Codex diplomaticus Brandenburgensis, 2. Haupttheil, Bd. 1, ed. A.F. Riedel, Berlin 1843, nr 110. Jest to ten sam dokument, którego listę świadków wypisał Bartłomiej Scultetus w XVI wieku; por. wyżej, przyp. 59, oraz R. Jecht, Geschichte der Stadt Görlitz..., t. I/1, s. 16. 
mentu z 1282 roku niejakiego Wityga de Kunstinsdorf, piszącego się z niewielkiej osady wiejskiej położonej w rejonie późniejszej Konsulstrasse ${ }^{77}$.

Za tym, że rozdanie dóbr podzgorzeleckich w lenno musiało nastapić znacznie wcześniej, jeszcze za Przemyślidów, przemawia także fakt, że żadnymi włościami w tych stronach nie zostało obdarowane nadnyskie zgromadzenie marienthalskie. Najbliższe dobra monarsze, jakie w okresie fundacji Marienthalu, czyli w latach 30. XIII wieku, pozostały jeszcze w rękach króla Wacława, leżały poza możliwym zasięgiem ówczesnej jurysdykcji zgorzeleckiej, za wzgórzami Königshainer Berge (były to, później tak nazwane, klasztorne Dolne Wsie, niem. Niederdörfer), a i w tych stronach w celu odpowiedniego zaokraglenia darowizny król musiał się uciec do konfiskaty ${ }^{78}$.

Nie sposób tak szybkiej utraty przez królów bezpośredniej władzy nad świeżo lokowanymi przecież wsiami traktować jako zjawiska przypadkowego. Najwyraźniej Przemysł Ottokar I i Wacław I po prostu jako najlepsze rozwiązanie z perspektywy organizacji zarządu przyjęli wypuszczenie maksimum należących do nich dóbr w lenno, co znacznie upraszczało zarząd tymi włościami, umożliwiając zarazem utrzymanie sporej grupy rycerstwa. Postępowanie takie wydaje się o tyle racjonalne, że obaj władcy na Górnych Łużycach bywali niezbyt często $^{79}$. Nie wiadomo także nic o rozporządzaniu przez nich w tym regionie jakimkolwiek dworem, którego utrzymanie i zaopatrzenie wymagałoby wydzielenia dla jego potrzeb dominium ziemskiego ${ }^{80}$. W razie swojego pobytu we wschodniej części Górnych Łużyc Przemysł Ottokar I i Wacław I mogli zresztą skorzystać z istniejącego tu od XI wieku i działającego zapewne jeszcze w drugiej połowie XII wieku ${ }^{81}$ systemu servitii regis, a przede wszystkim z walorów rezydencjonalnych zamku Landeskrone i zasobów należących doń dóbr.

77 BUWr., Akc. 1947/5, p. 102, fol. 49v: Henricus de Camentz, Johannes plebanus in Gōrlitz, Witecko de Kunstinesdorff, Henricus de Radeberg, Petrus [der] Sigeman, Volpertus advocatus in Berhartsdorff, Bercheremus de Radeberg, Rudolfus de Lubano, Henricus de Lapidea domo, Herrmannus de Grunaro [recte: Grunaw], Waltherus magister Hospitalis, Petzoldus de Konigshain, Nicolaus filius Dni Witegonis de Kunstinesdorff, et alii quam plures. Por. tu także W. Jecht, Neue Untersuchungen..., s. 20; R. Jecht, Geschichte der Stadt Görlitz, s. 29. O samej miejscowości zob. idem, Geschichte der Stadt Görlitz..., t. I/2: Topographie der Stadt Görlitz, Görlitz 1927-1934, s. 575-576; o lennym charakterze jej dzierżenia przez kolejnych właścicieli: idem, Geschichte der Stadt Görlitz ..., t. I/1, s. 29.

78 Za poszkodowanych w wyniku owej konfiskaty uważali się bracia Nostitzowie, zob. CDLS I, 63. Por. tu także M. Jänecke, Die oberlausitzer Herrschaften ..., s. 135-136; H. Helbig, Die Oberlausitz ..., s. 84; J. Zdichynec, Klášter..., s. 196.

79 Por. uwagi R. Jechta, Geschichte der Stadt Görlitz, t. I/1, s. 41, dotyczące czasów panowania przemyślidzkiego i askańskiego, a także zestawienia wizyt Przemyślidów nad Nysą i Sprewą: H. Knothe, Urkundliche Grundlagen..., s. 181 przyp. 1, oraz R. Jecht, Geschichte der Stadt Görlitz..., t. I/1, s. 34.

80 W Zgorzelcu władcy czescy mogli mieć jedynie dom, z czasem podarowany mniszkom z Marienthalu: CDLS I, 53; por. też G. Köhler, Der Nonnen Haus zu Görlitz, NLM 1849, Bd. 26, s. 288-291 (związek tego dokumentu ze Zgorzelcem jest jednak niepewny; por. J. Bauermann, Die ältesten Urkunden..., s. 120-121, przyp. 5, tam dalsze odsyłacze).

81 Jeśli słuszna jest identyfikacja Zgorzelca jako Melca w tzw. Indiculus curiarum, por. M. Kobuch, Zur Lagebestimmung der Wirtschaftshöfe des Staufischen Tafelgüterverzeichnisses in meissnischen Markengebiet [w:] Deutsche Königspfalzen 4: Pfalzen-Reichsgut-Konigshofe, ed. L. Fenske, s. 356-368; por. też J. Huth, Die siedlungsgeschichtlichen Grundlagen und Voraussetzungen für die Stadtwerdung von Görlitz und Löbau, „Lětopis, Reihe B: Geschichte” 1871, Bd. 18, s. 211-217; G.E. Schrage, Die Oberlausitz..., s. 64. O tym, że servitium regis było należne ze Zgorzelca jeszcze jako zwykłej wsi już przed 1071 rokiem, świadczy dokument oznajmujący podarowanie ośmiu łanów królewskich w tej miejscowości biskupstwu miśnieńskiemu (CDS II 1, 31). 


\section{Włodarstwo a sołtystwo zgorzeleckie}

Podsumowując dotychczasowe wywody, trzeba stwierdzić, że wedle wszelkiego prawdopodobieństwa już przed 1253 rokiem zakres obowiązków ewentualnego włodarza zgorzeleckiego poza obszarem jurysdykcji miejskiej ograniczałby się do administrowania dochodami płynącymi z tych spośród kilkunastu podzgorzeleckich miejscowości, które mogły wówczas nie być jeszcze wypuszczone w lenno, oraz sprawowania w nich sądownictwa dominialnego. Powstaje pytanie: czy dla zawiadywania tą skromną i nietrwałą wiązką uprawnień trzeba było powoływać osobnego urzędnika ${ }^{82}$ ? A może w zakresie obowiązków zgorzeleckiego włodarza leżały także czynności podejmowane w granicach miasta?

Powołanie specjalnego włodarza do zarządzania dochodami z miasta wydaje się możliwe w odniesieniu do dużych ośrodków, źródła XIII-wieczne dotyczące większych miast środkowoeuropejskich nie wspominaja jednak o takiej instytucji. Włodarze książęcy zajmujący się pobieraniem dochodów z miast lokacyjnych mieli natomiast, według Karola Modzelewskiego, działać w XIII wieku w Wielkopolsce: w Pyzdrach i Kaliszu ${ }^{83}$. Bliższe przyjrzenie się zarówno właściwym wzmiankom źródłowym, jak i ich interpretacji przez przywołanego badacza upewnia jednak, że w żadnym razie nie chodziło tu o urzędników wyłącznie lub głównie zajmujących się pobieraniem dochodów z miast. W pierwszym z przytoczonych przypadków włodarska funkcja Piotra Świrkowicza, określonego w pewnym dokumencie jako włodarz pyzdrski, odnosiła się właściwie nie do lokacyjnego miasta, lecz do pobliskiego dworu w Dłusku ${ }^{84}$. Jest oczywiście prawdopodobne, że ów Piotr mógł pobierać określone dochody z komunalnego miasta na potrzeby zarządzanego przez siebie dworu książęcego, podobnie jak klucznicy leśnicki i brzeski na Ślassku pobierali dochody z lokacyjnych wsi w okolicy, lecz nie zmienia to faktu, że były to jedynie pewne dodatkowe, delegowane im uprawnienia ${ }^{85}$.

W kontekście domniemanych włodarstw miejskich znacznie ciekawszy wydaje się dokument z 10 sierpnia 1294 roku potwierdzający przeniesienie ogrodników ze Starego Miasta Kalisza na prawo niemieckie. Występuje w nim włodarz jako osoba powołana przez wystawcę, Przemysła II, do sądzenia owych ogrodników zgodnie z zasadami prawa niemieckiego ${ }^{86}$. Przywołana $\mathrm{w}$ tym samym dokumencie kompetencja owego wło-

82 Pytanie to staje się tym bardziej zasadne, jeśli za Hermannem Knothe i kontynuatorami przyjąć funkcjonowanie w Zgorzelcu królewskiego landwójta, który raczej nie utrzymałby się tylko z przypadającej mu jednej trzeciej dochodów z sądownictwa in maioribus.

83 Tak K. Modzelewski, Włodarz..., s. 528.

84 Zob. K. Modzelewski, Organizacja..., s. 57; por. KDW I, 500; KDW II, 904. Miasto Pyzdry w okresie sprawowania przez Piotra włodarstwa miało ponadto własnego wójta dziedzicznego, zob. KDW I, 498; KDW VI, 30. Por. tu także sugestię R.M. Czerniaka we wstępie do książki J. Łojki, Civitas Pyzdry. Dzieje miasta do roku 1793, Pyzdry 2007, s. 3-4, że dwór znany w źródłach jako położony w Dłusku znajdował się rzeczywiście w miejscu, gdzie stanął zamek w Pyzdrach, co wyjaśniałoby wymienne stosowanie obu toponimów.

85 Szerzej o tym por. K. Modzelewski, Organizacja..., s. 59-61.

$86 \mathrm{KDW}$ II, $\mathrm{nr}$ 723: damus et concedimus ipsis ius Theutonicum, eximendo ipsius omni iure Polonico et vexatione qualibet Polonica [...], et in iudiciis et causis ipsorum non teneantur coram aliquo homine respondere vel quomodolibet litigare, nisi coram nostro vladario per ipsum ad iudicium, prout mos est Theutonicus, racionabiliter advocati. Et si ipsis contingat homicidium perpetrare, vel in bonis ipsorum 
darza do sądzenia in maioribus wskazuje jednak, że nie chodzi tu o lokalnego zarządcę dóbr książęcych, lecz o wysokiego dygnitarza, prokuratora domeny książęcej w ziemi kaliskiej ${ }^{87}$. Sprawując sądownictwo nad wspomnianymi ogrodnikami, po prostu wypełniał on swe obowiązki, jako że w świetle tego dokumentu w momencie przeniesienia ich na prawo niemieckie nie należeli oni do obszaru jurysdykcji miasta Kalisza.

Przytoczone przypadki wielkopolskie wskazuja, że jeśli w danym mieście lub jego pobliżu nie mieścił się dwór monarszy - a w Zgorzelcu, jak wskazano wyżej, nie było takowego, gdyż jego funkcję mógł z powodzeniem pełnić zamek Landeskrone - wówczas pod nazwą villicus powinien kryć się urzędnik zarządzający szeroko pojętą domeną panującego obejmującą dochody i uprawnienia władcy na danym terytorium. W realiach znanych z zasiedlanych i reorganizowanych w XIII wieku obszarów Królestwa Czech, krajów wettyńskich i Śląska w tej roli można się spodziewać wójta/sołtysa miejskiego (dziedzicznego bądź stanowionego ${ }^{88}$ ), czasem sprawującego urząd landwójtowski, albo niebędącego wójtem/sołtysem miejskim landwójta: prowincjonalnego ${ }^{89}$ bądź okręgowego $^{90}$. W przypadku villici zgorzeleckiego Floryna w grę nie wchodzą dwa ostatnie przypadki, gdyż, jak już wspomniano, równolegle z nim występował advocatus Wolfram, zależnie od przyjmowanego poglądu na istnienie w tym regionie landwójtostw - albo landwójt zgorzelecki, albo wójt krajowy budziszyński ${ }^{91}$. Trzeba zatem przyjąć, że rację miał J. Bauermann, twierdząc, iż Floryn był sołtysem miejskim zgorzeleckim.

Ten dedukcyjny wniosek można bez trudu podeprzeć wnioskowaniem indukcyjnym. Po pierwsze, jak wskazano już wyżej, choć prawdopodobni potomkowie Floryna nie zostali poświadczeni na zgorzeleckim sołtystwie dziedzicznym ${ }^{92}$, niewatpliwie jednak

per quemcumque perpetrari, has causas et omnia quecunque inter ipsos orientur idem noster vladarius determinabit.

87 Wymienne użycie tytułów prokuratora i włodarza poświadcza dokument z 1290 roku, w którym Wiktor, skądinąd znany jako procurator (zob. KDW I, 536; KDW II, 642, 674, 763), wystapił jako flodarius (KDW II, 641); por. także: K. Modzelewski, Chłopi w monarchii wczesnopiastowskiej, Wrocław 1987, s. 139 , przyp. 21.

${ }_{88} \mathrm{Na}$ przykład w przypadku tak zwanych miast willikacyjnych (czes. villikačných) w Czechach por. W. Weizsäcker, Zur Geschichte..., s. 3-4. Kategorie wójtów wieczystych i czasowych rozróżniano także na Śląsku, por. Urkundensammlung zur Geschichte des Ursprungs der Städte und der Einführung und Verbreitung Deutscher Kolonisten und Rechte in Schlesien und der Ober-Lausitz, ed. G.A. Tzschoppe, G.A. Stenzel, 13, Hamburg 1832, s. 290-291.

89 Wliczając tu czeskich i morawskich włodarzy-prokuratorów prowincji, por. L. Jan, Vzník..., s. 42-45, passim; J. Žemlička, Počatký Čech královských 1198-1253: Proměna státu a společností, Praha 2002, s. 555; idem, Kasteláni..., s. 119, passim. Pomijam tu, żywo ostatnio dyskutowaną w piśmiennictwie czeskim, sprawę związku owych villicorum morawskich z włodarzami grodowymi, nieistotną dla głównego wątku niniejszego artykułu.

90 Pewien szczególny przypadek stanowi Lipsk, gdzie istniał zarówno wójt z nadania królewskiego, jak i włodarz margrabiowski, a niezależnie od tego sołtys miejski; zob. CDS II 8, 3 (1216); por. też C.W. Böttiger, Geschichte des Kurstaates und Königreiches Sachsen, t. I, Hamburg 1830, s. 149.

91 Za pierwszą ewentualnością opowiedział się R. Kötzschke, Vogtei..., s. 161, za drugą natomiast J. Bauermann, Die ältesten Urkunden ..., s. 123 i M. Reuther, Verfassung..., s. 85-86, 104.

92 Które, notabene, w okresie lepiej już opisanym w źródłach dość często zmieniało właścicieli (por. R. Jecht, Geschichte der Stadt Görlitz ..., t. I/1, s. 47-48). Zwraca także uwagę brak uchwytnych w źródłach innych składników uposażenia zgorzeleckiego sołtystwa niż trzecia część opłat sądowych; przemawia to za dość szybką alienacją ewentualnych pozostałych uprawnień (por. przegląd składników uposażenia wójtostw śląskich w: G.A. Tzschoppe, G.A. Stenzel, Geschichtliche Einleitung [w:] Urkundensammlung..., s. 182-187, przyp. 88. 
weszli oni w skład tutejszego patrycjatu ${ }^{93}$. Po drugie, istnieje wzmianka źródłowa z 1285 roku, więc już z okresu rządów askańskich, w której inny zgorzelecki sołtys dziedziczny wystapił jako villicus ${ }^{94}$. Dość długi okres urzędowania Floryna ${ }^{95}$ wskazuje przy tym, że najpewniej dzierżył on zgorzeleckie sołtystwo jako lenno. Za domysłem tym przemawia także prawdopodobny udział Floryna w kolonizacji okolic Zgorzelca ${ }^{96}$ oraz jego wystapienie wśród komisarzy przeprowadzających rozgraniczenie dóbr królewskich i biskupich. Jak wskazują przykłady śląskie, z których najstarszy jest współczesny pierwszej wzmiance o Florynie ze Zgorzelca ${ }^{97}$, to właśnie dziedziczni sołtysi/wójtowie miejscy wykonywali bowiem w terenie wielki plan zasiedlenia puszcz przez zakładanie dystryktów wiejsko-miejskich.

Nie od rzeczy będzie w tym miejscu wskazać, że to zapewne właśnie Floryn był zasadźca, który dał początek komunalnemu miastu Zgorzelec ${ }^{98}$. Wskazano już w dotychczasowym piśmiennictwie, że początek głębszego zainteresowania Przemysła Ottokara I sprawami górnołużyckimi można umiejscowić już w 1213 roku, kiedy to odnotowano pierwsze pojawienie się tego władcy w Budziszynie w związku z wytyczaniem granic posiadłości królewskich i biskupich oraz zamierzoną fundacją kapituły w grodzie nad Sprewą ${ }^{99}$. Sytuacja osadnicza, jaka znalazła odzwierciedlenie w tak zwanym Górnołużyckim Dokumencie Granicznym (oddającym stan sprzed 1228 roku, zapewne z 1223 roku), przedstawia wyraźnie obraz kraju wciąż w znacznej mierze niezasiedlonego, pełnego słowiańskich oronimów i hydronimów ${ }^{100}$. Zakładanie nowych wsi leśno-łanowych musiało już jednak w owym czasie trwać, także we wschodniej części kraju, o czym świadczą pochodzące $\mathrm{z}$ tego okresu wzmianki o Gersdorfie pod Zgorzelcem ${ }^{101}$ i Kunnersdorfie pod Löbau ${ }^{102}$. Ta ostatnia miejscowość została w odnośnym dokumencie zlokalizowana prope oppidum Lubaw, co jest w ogóle najstarszą wzmianką o istnieniu na Górnych Łużycach komunalnego miasta królewskiego ${ }^{103}$. W tym kontekście jest prawdopodobne, że zasiedlenie późniejszych dystryktów Zgorzelca i Löbau wraz z loka-

93 Por. wyżej, przyp. 12.

94 Pełną treść owej listy świadków przekazał Kürbuch Sculteti, BUWr, Akc. 1947/5, p. 103, fol. 50r: Johannes plebanus in Görlitz, Henricus villicus in Görlitz, Herrmannus de Grunow, Hertwigus de Richenbach, Petzoldus de Königshain et Conradus filius suus, Petermannus de Königshain, Guntzelinus, Nicolaus et Schibanus frater [fratres?], Ertwicus et Lutoldus frater suus, et alii quam plures. Por. tu także R. Jecht, Geschichte der Stadt Görlitz, t. I/1, s. 48.

95 Jako minimum należy przyjąc okres 11 lat, jaki upłynął pomiędzy pierwszym a ostatnim wystapieniem Floryna w źródłach, należy jednak pamiętać, że już ok. 1223 roku znalazł się on w gronie komisarzy określonych jako doświadczeni w dokonywaniu rozgraniczeń posiadłości w regionie.

96 Por. wyżej, przyp. 13.

97 Mowa tu o przywileju biskupa Wawrzyńca dotyczącym kolonizacji miejsko-wiejskiej wokół Ujazdu: SUB I, 225.

98 Por. W. Jecht, Neue Untersuchungen..., s. 23-24; J. Bauermann, Die ältesten Urkunden..., s. 123, przyp. 1.

99 Zob. R. Jecht, Neues..., s. 69-70.

100 Por. W. Jecht, Neue Untersuchungen..., s. 23.

101 W tymże Górnołużyckim Dokumencie Granicznym rzeka Biała Szprewica (Weisser Schöps) wystąpiła jako Sprewe que defluit per Gerhartesdorf.

102 CDLS I, 14.

103 Por. uwagi W. Jechta, Neue Untersuchungen..., s. 55. Niewątpliwie przed 1225 rokiem musiało istnieć także pierwsze prywatne miasto Górnych Łużyc, Kamieniec (Kamenz); por. CDS II 7, 1. 
cjami tych miast nastapiło pomiędzy 1213 a 1221 rokiem $^{104}$. Przypuszczalnie więc, gdy Floryn ze Zgorzelca po raz pierwszy pojawił się w źródłach około 1223 roku, nie był on bynajmniej włodarzem (jako taki, z braku w Zgorzelcu królewskiego dworu, nie miałby przecież czym zarządzać), lecz sołtysem świeżo lokowanego miasta.

\section{Ostritz: dominialne włodarstwo czy królewskie sołtystwo?}

Nie mniejszą zagadką niż sprawa statusu zgorzeleckiego villici Floryna jest problem zdefiniowania funkcji sprawowanej przez określonego w 1241 roku tą samą nazwą urzędnika lub funkcjonariusza w Ostritz, imieniem Henryk. Jak wskazano już wyżej, wątpliwości w jego przypadku dotyczą nie tylko charakteru sprawowanego przezeń urzędu bądź funkcji, lecz także osoby mocodawcy, którą mógł być albo król Wacław ${ }^{105}$, albo Henryk II, syn Ottona I burgrafa von Dohna ${ }^{106}$.

Kluczem do rozwiązania tej łamigłówki jest sam dokument, w którym wymieniony został Henryk wraz z braćmi ${ }^{107}$. Dyplom ten wykazuje dyktat odbiorcy (tj. Marienthalu) i daje dzięki temu współczesnym interpretatorom dokładny wgląd $\mathrm{w}$ rzeczywiste stosunki panujące „w terenie”, czyli w samej włości Ostritz. Względem praw własnościowych sprzedawców przedmiotowej nieruchomości sformułowanie dokumentu jest jednoznaczne: Henryk wraz z braćmi trzymali Seifridsdorf jako lenno wprost od kró$\mathrm{la}^{108}$. Wymowę tego sformułowania dodatkowo podkreśla dalszy passus dokumentu, w którym jest mowa o zapłaceniu czterdziestu grzywien Henrykowi von Dohna, qui se ius aliquod habere in eodem predio testabatur. Sformułowanie to w sposób czytelny ujawnia intencje nabywczyń, które wprawdzie chciały zaspokoić roszczenia Henryka von Dohna, najwyraźniej jednak wolały nie umieszczać w przedstawionym królowi koncepcie dokumentu potwierdzającego transakcję stwierdzeń sugerujących, że monarcha z góry uznawał ich zasadność. Tak oględne potraktowanie domniemanych uprawnień

104 Por. W. Jecht, Neue Untersuchungen..., s. 55-56; oraz R. Jecht, Geschichte der Stadt Görlitz, t. I/1, s. 32-33. W przypadku Zgorzelca można jednak liczyć się także z nieco wcześniejszym startem kolonizacji wiejskiej, za czym mogą przemawiać daty dendrochronologiczne uzyskane z belek ramy dachowej kościoła w Ludwigsdorfie, pochodzące ze schyłku XII wieku; zob. J. von Richthofen, Bieżuńczanie - Milczanie - Serbowie. Stowiańskie osadnictwo na niemieckich i polskich Górnych Łużycach po obu stronach Nysy [w:] Milicz: Clavis Regni Poloniae. Gród na pograniczu, red. J. Kolenda, Wrocław 2008, s. 285, przyp. 16.

105 R. Kötzschke, Vogtei..., s. 161; H. Helbig, Die Oberlausitz ..., s. 83; G.E. Schrage, Die Oberlausitz ..., s. 69; eadem, Bautzen und das Land Milsza in der Zeit um 1000 [w:] Besunzane - Milzener - Sorben: Die slawische Oberlausitz zwischen Polen, Deutschen und Tschechen, Schriftenreihe der Städtischen Sammlungen für Geschichte und Kultur Görlitz, N.F. 37, Görlitz-Zittau 2004, s. 37; L.-A. Dannenberg, Ostritz..., s. 183-184; tam dalsze odsyłacze.

106 H. Knothe, Die Burgrafen von Dohna..., s. 204; idem, Urkundliche Grundlagen..., s. 175, przyp. 2. Za wynik nieporozumienia uznać trzeba określenie przez Jana Zdichynca, op.cit., s. 202, przyp. 183, samego Ottona von Dohna jako villici królewskiego.

107 CDLS I, nr 37. Zrezygnowano w tym miejscu z cytowania nowszej edycji (CDB IV, nr 9), gdyż najważniejszy dla materii niniejszego tekstu passus źródła został dokładniej oddany właśnie w CDLS; por. o tym R. Doehler, Diplomatarium ..., s. 15, nr 5, oraz niżej, przyp. 110.

${ }_{108}$ Nos igitur villam pretaxatam, in manus nostras a prefatis fratribus resignatam, siquidem eam a nobis in pheudo habuerunt... Por. tu G. E. Schrage, Bautzen und das Land Milsza..., s. 37. 
Henryka von Dohna wskazuje, że z perspektywy króla Wacława rodzina ta prawdopodobnie nie mogła rościć sobie pretensji do zwierzchnictwa nad Seifridsdorfem mimo iż dysponowała wówczas całą włością Ostritz. Powstaje pytanie: dlaczego?

Chcąc dochować wierności tenorowi źródła, należy przyjąć, że villicus Henryk wywodził swe prawa $\mathrm{z}$ bezpośredniej królewskiej inwestytury, która nastapiła przed powierzeniem włości Ostritz Doninom ${ }^{109}$. Za domniemaniem tym przemawia niewatpliwie fakt dysponowania prawami do Seifridsdorfu przez trzech braci oraz możliwość wniesienia roszczeń przez potencjalnych spadkobierców (których konsens został wymieniony w przedmiotowym dokumencie), co sugeruje dzierżenie owego lenna już przez ojca sprzedawców z 1241 roku (być może imieniem Zygfryd, sądząc z nazwy miejscowości). Jeśli rzeczywiście tak było, to podobnie jak w przypadku Zgorzelca retrospektywna ekstrapolacja źródeł prowadzi do początków wieku XIII, gdy w całym kraju dopiero rozpoczynała się szeroko zakrojona akcja kolonizacyjna. Czyżby zatem villicus Ostritz pełnił w niej analogiczne zadania jak Floryn, villicus zgorzelecki?

Twierdząca odpowiedź na to pytanie podsuwa kolejne, z pozoru dziwne, sformułowanie użyte w dokumencie potwierdzającym sprzedaż Seifridsdorfu przez Henryka, Rudolfa i Hartmana. Będąca przedmiotem transakcji miejscowość została w nim bowiem, nieco zaskakująco, umieszczona nie in territorio czy in districtu miasteczka Ostritz, nawet nie pod nim czy koło niego, lecz po prostu in dicto oppido ${ }^{110}$. Jeśli zaś wioska, którą dzierżył villicus Ostritz wraz ze swą rodziną jako lenno dziedziczne, leżała na terytorium owego miasteczka, uzyskamy zaskakującą odpowiedź na nierozstrzygnięte dotąd w historiografii pytanie, czy włodarz Ostritz był urzędnikiem królewskim, czy funkcjonariuszem dominialnym. Otóż był on urzędnikiem królewskim, tyle że najpewniej nie włodarzem, lecz sołtysem dziedzicznym Ostritz! Dzięki względnej obfitości materiałów źródłowych z sąsiedniego Śląska wiadomo przecież, że sołtystwa dziedziczne (tam zwane raczej wójtostwami) wraz z należącym do nich uposażeniem były przekazywane zasadźcom jako dziedziczne lenno (Erblehn) i bywały często uposażane czy to konkretnymi osadami podmiejskimi, czy też gruntem pod lokację takowych ${ }^{111}$.

Omówiony wyżej szczegółowo dokument z 1241 roku to jedyne źródło traktujące o dziedzicznym sołtystwie Ostritz. Kolejna wzmianka o przedstawicielu władztwa gruntowego w tym miasteczku pochodzi z 1289 roku i nie sposób rozstrzygnąć, czy dotyczy ona włodarza, sołtysa, czy może lennika, któremu Doninowie powierzyli samo Ostritz lub całą włość ${ }^{112}$. W każdym razie można sądzić, że jeszcze przed zbyciem przez Doninów Ostritz na rzecz Marienthalu w 1294 roku $^{113}$ tutejsze dziedziczne sołtystwo

109 Teoretycznie można także wyobrazić sobie, że przedmiotem nadania był jedynie teren pod lokację Seifridsdorfu, położony poza obrębem włości Ostritz - wówczas nadanie mogłoby nastapić także po inwestyturze Doninów na włości Ostritz - co jednak jest niemożliwe ze względu na umiejscowienie owej wsi in oppido (por. dalej).

110 Tak w CDLS. Joachim Prochno w swym zbiorze regestów (Regesten..., przyp. 21) oraz wydawcy tego tomu CDB nadgorliwie poprawili in oppido na sub oppido. Sprawę tę w oryginale tego dokumentu sprawdził R. Doehler, Diplomatarium..., s. 15, nr 5, przyp. 4, stwierdzając, że figuruje tam wyraźnie zwrot in oppido; por. także R. Kötzschke, Vogtei..., s. 161: „im Stadtbereich”.

111 Por. przeglądowo G.A. Tzschoppe, G.A. Stenzel, Geschichtliche Einleitung..., s. 181-187, passim.

112 CDLS I, 81

113 Przedmiotem tej transakcji oprócz z dochodów z miasta była jurysdykcja w nim samym i w całej włości (J. Prochno, Regesten..., 52-53; por. także CDLS I, 257, s. 376, gdzie burgrafów von Dohna wskazano wprost jako właścicieli klucza dóbr Ostritz przed zbyciem miasteczka na rzecz Marianthalu). 
było już w posiadaniu panów gruntowych, gdyż brak źródłowych śladów wykupu takowego przez Marienthal w późniejszym okresie. Advocati Ostritz wzmiankowani po nabyciu miasteczka przez zgromadzenie byli już, wedle wszelkiego prawdopodobieństwa, wójtami klasztornymi ${ }^{114}$, a w roli przedstawicielstwa mieszczan Ostritz w XIV wieku występowało kolegium ławników ${ }^{115}$. Wydaje się, że los sołtystwa dziedzicznego Ostritz nie jest zjawiskiem nieodosobnionym, gdyż podobnie przebiegało to $\mathrm{w}$ odniesieniu do innych małych miast, które zapewne już w czasach przemyślidzkich przeszły w ręce prywatne (Reichenbach, Weissenberg). Jedyne wzmianki o rezydujących w nich królewskich urzędnikach pochodzą z wielokrotnie tu cytowanych przywilejów dla Marienthalu $\mathrm{z}$ lat $1238-1239^{116}$.

\section{Jurysdykcja sołtysów poza murami miast a geneza górnołużyckich weichbildów}

Utożsamienie znanych ze źródeł villicorum Zgorzelca i Ostritz z dziedzicznymi sołtysami tych miast nakazuje - wobec braku dowodów na istnienie na Górnych Łużycach pod rządami Przemyślidów domniemanych wójtów okręgowych ${ }^{117}-\mathrm{w}$ nich właśnie domyślać się owych advocatorum miast królewskich, od których jurysdykcji zwolnione zostały posiadłości marienthalskie przywilejami z lat 1238-1239. Wskazano już wyżej, że dane tych dokumentów trudno tak po prostu zignorować, przyjmując za J. Bauermannem bezmyślne odpisanie przez koncypienta sformułowań z podobnych dokumentów wystawionych przez Wettynów dla zgromadzenia Altzelle. Przychylając się do zdroworozsądkowej konstatacji Rudolfa Kötzschkego, że lista miast zawarta $\mathrm{w}$ owych przywilejach powinna odzwierciedlać rzeczywiście istniejące $\mathrm{w}$ latach

114 Byli to mianowicie: w 1326 roku niejaki Sevinus (CDLS I, 185) lub Gerung (J. Prochno, Regesten..., 107), a w 1334 roku: Jan von Grisslau (CDLS I, 219). We wzmiance z 1364 roku (przytoczonej, z błędnym numerem regestu, przez J. Zdichynca, Klášter..., s. 179, przyp. 61), w której miał występować wójt klasztorny, nie ma takiego urzędnika.

115 Tak w każdym razie podczas głośnego konfliktu z Żytawą w latach 70. XIV wieku; zob. Jahrbücher des zittauischen Stadtschreibers Johannes von Guben und einiger seiner Amtsnachfolger [w:] Scriptores Rerum Lusaticarum, N.F., t. I, Görlitz 1839, s. 44.

116 Można wręcz odnieść wrażenie, że w drugiej połowie rządów Wacława I rozpoczęło się lub w ogóle nastapiło Górnych Łużycach świadome rozrzedzenie sieci miast i włości królewskich mające na celu jej racjonalizację, w każdym razie Reichenbachu i Weissenbergu nie ma już na liście miast królewskich sporządzonej przy okazji podziału kraju w 1268 roku.

117 Por. wyżej pkt 78, s. 10-12. Istnienie takiej funkcji urzędniczej osobnej od sołtystw miejskich byłoby szczególnie absurdalne w przypadku małych ośrodków otoczonych niewielką liczbą wsi: Weissenbergu i Reichenbachu. Aby mógł się tam utrzymać landwójt, po prostu musiał on być tożsamy z sołtysem głównego miasta. Tym bardziej nieprawdopodobna jest w tym kontekście hipoteza L.-A. Dannenberga, jakoby villicus z uprawnieniami sądowniczymi in maioribus działał w niewielkim Ostritz, otoczonym włością liczącą raptem sześć miejscowości wraz z nim wypuszczonych w lenno panom von Dohna (Ostritz..., s. 184). W związku z brakiem Ostritz na liście miast będących siedzibami królewskich urzędników w latach 1238-1239 należy raczej przyjąć, że jurysdykcję dominialną we włości Ostritz sprawowali jej lenni dzierżyciele, Doninowie, a sądownictwo in maioribus w imieniu króla - wójt krajowy budziszyński. 
30. XIII wieku zagrożenia dla nadawanego w nich immunitetu sądowego ${ }^{118}$, warto się zastanowić, w jakim zakresie i wobec kogo mogli sprawować jurysdykcję sołtysi królewskich miast poza ich obrębem.

Wbrew większości dotychczasowych interpretatorów trzeba przede wszystkim wskazać, że obydwa przywileje dla Marienthalu w najmniejszym stopniu nie dowodzą sprawowania przez wszystkich wymienianych w nich urzędników rezydujących w królewskich miastach sądownictwa in maioribus ${ }^{119}$. Pozornie taka kompetencja królewskich urzędników wynika z treści obydwu dokumentów, w których zwolniono poddanych Marienthalu od jurysdykcji królewskich urzędników, z zastrzeżeniem utrzymania przez władcę sądownictwa w sprawach ,większych”, zdefiniowanych tu przez wyliczenie odpowiednich deliktów ${ }^{120}$. Ze sformułowań użytych w dokumentach wynika, że zarówno wyższe, jak i niższe sądownictwo mogło podlegać wszystkim wymienionym w nich urzędnikom nazwanym wójtami. Czy jest jednak możliwe, że już w pierwszej połowie XIII wieku każdy z górnołużyckich sołtysów miejskich rozporządzał jurysdykcją in maioribus wobec mieszkańców pobliskich wsi?

O tym, że tak nie było, przekonuje przyjrzenie się późniejszym przywilejom dwóch miast wymienionych w dokumentach marienthalskich, Zgorzelca i Löbau. Choć zgorzelecki sąd miejski już w 1303 roku przejął większość kompetencji działającego tam do tego czasu sądu wójtowskiego (Vogtding, Echte Ding), przynajmniej w odniesieniu do mieszczan, lecz in maioribus jeszcze wtedy nadal miał orzekać sąd, który gaił i któremu przewodniczył wójt krajowy, tyle że skład orzekający mieli stanowić sołtys i ławnicy zgorzeleccy $^{121}$. Skoro zatem nawet ta gruntowna reforma sądownictwa w ziemi zgorzeleckiej nie pozwoliła sądowi dziedzicznego sołtysa na sądzenie kogokolwiek in maiori$b u s$, tym bardziej nie sposób przypuścić, by takie lub podobne uprawnienie sąd ów mógł mieć przed 1303 rokiem, i to poza obszarem miasta. Podobnie wygląda to w odniesieniu do Löbau. Miasto to dopiero na początku XIV wieku otrzymało bowiem od margrabiów brandenburskich dwa szerokie przywileje, na mocy których mieszkańcy okolicznych wsi mieli omnia judicia sua tam maiora quam minora odprawować przed sądem jego sołtysa dziedzicznego ${ }^{122}$.

Z przytoczonych przykładów wynika, że sołtysi dziedziczni Zgorzelca i Löbau nawet nad mieszczanami tych ośrodków nie sprawowali do początku XIV wieku jurysdykcji in maioribus, która zastrzeżona była dla wójtów krajowych. Tym bardziej nie należy przypuszczać, by tak ważnym i pilnie strzeżonym przez monarchów uprawnieniem dys-

118 Autor ten (R. Kötzschke, Vogtei..., s. 160) słusznie wskazał, że dodatkowej wiarygodności listom siedzib królewskich advocatorum przydaje wystapienie na nich niewielkich ośrodków, jakimi były Reichenbach i Weissenberg, szczególnie w kontekście położenia tzw. dolnych wsi klasztornych. Pośrednimi przesłankami wskazującymi na istnienie jakichś kompetencji sołtysów poza miastami mogą być: wystapienie Floryna ze Zgorzelca wśród komisarzy, którzy burquardos terrarum [...] distinxerunt, oraz nabycie przez Marienthal miasteczka Ostritz w 1294 roku cum iudicio nad wszystkimi wsiami klucza (J. Prochno, Regesten..., 52).

119 Por. tu J. Zdichynec, op.cit., s. 174 (immunitet sądowy z przywilejów marienthalskich z lat 1238-1239 zinterpretowany jako wyłączenie spod niższego sądownictwa).

120 Urzędnicy królewscy mieli być mianowicie tantum de furtis, homicidiis, membrorum mutilacione et stupri violencia iudicaturii.

121 CDLS I, 113.

$122 \operatorname{CDS}$ II 7, 6, 9.

Artykuły - Articles 
ponowali odpowiedni urzędnicy rezydujący w niewielkich miasteczkach Weissenberg i Reichenbach ${ }^{123}$. Rzekome uprawnienia do sądownictwa wyższego urzędników we wszystkich miastach wymienionych $\mathrm{w}$ przywilejach z lat 1238-1239 należy zatem złożyć na karb niezręczności użytych w tych dyplomach sformułowań wynikłych ze skopiowania odpowiednich partii dokumentów margrabiowskich dla Altzelle. Niemniej lista urzędników rezydujących w miastach królewskich, spod których jurysdykcji wyłączone zostały w odnośnych dokumentach posiadłości marienthalskie, pozostaje wiarygodna jako zestawienie osób przynajmniej potencjalnie uprawnionych do sądzenia także poza granicami miast $w$ niektórych sprawach niezaliczanych do sądownictwa wyższego.

W poszukiwaniu podstaw owej jurysdykcji warto zwrócić uwagę na pewien ważny szczegół związany z przebiegiem kolonizacji Górnych Łużyc w pierwszej połowie XIII wieku oraz wynikającym z niego kształtem organizacji terytorialnej. Otóż w regionie tym, jak wskazano wyżej, nie istnieli wprawdzie królewscy wójtowie okręgowi, lecz całe sądownictwo in maioribus spoczywało w rękach budziszyńskiego wójta krajowego (iudex provincialis), zarazem jednak kraj był wyraźnie podzielony na włości, których centra stanowiły królewskie miasta. Badacze dziejów regionu już dawno dostrzegli, że wokół królewskich miast górnołużyckich rozciagały się zwarte obszary osadnictwa wiejskiego całkowicie zdominowane przez niewielkie posiadłości lenne pozostające w posiadaniu rycerstwa i mieszczan ${ }^{124}$. Taka struktura osadnicza zachowała się w sposób modelowy do czasów nowożytnych wokół Zgorzelca i Löbau; w przypadkach Reichenbachu, Weissenbergu i Ostritz nie zdołała się natomiast rozwinąć ze względu na bliskość innych kompleksów dóbr (w tym obdarzonych szczególnymi prerogatywami w dziedzinie sądownictwa: Kittlitz, Baruth i dominium biskupiego), a także szybkie przekazanie tych miast wraz z ich przyległościami w lenno. W tym kontekście zwraca także uwagę niemal całkowita zbieżność listy miast królewskich $\mathrm{z}$ dokumentów marienthalskich z lat 1238-1239 z listą ośrodków powstałych w XIII wieku archiprezbiteratów ${ }^{125}$, co wyraźnie sugeruje oparcie struktur zarządu na królewskich miastach już za panowania Przemysła Ottokara I i w początkach rządów Wacława I, przed przekazaniem Reichenbachu i Weissenbergu w ręce prywatne.

Okręgi otaczające królewskie miasta łatwo poddają się interpretacji jako zjawisko osadnicze: ich powstanie było rezultatem zasiedlenia wybranych partii kraju na bezpośrednie zlecenie królewskie - w przeciwieństwie do innych subregionów Górnych Łużyc, gdzie powstały tak zwane władztwa, skolonizowane wprawdzie także na polecenie monarchów, lecz pod kierunkiem możnowładców i zapewne za ich pieniądze ${ }^{126}$. Nietrudno przy tym dostrzec, że wszystkie miasta, które były siedzibami wymienionych w latach 1238-1239 advocatorum oraz stały się ośrodkami archiprezbiteratów, kontrolowały główną magistralę komunikacyjną kraju - odcinek Viae Regiae zwany Wysoką

123 Jurysdykcją in maioribus dysponował za to z pewnością rezydujący w Budziszynie wójt krajowy.

124 W. Jecht, Neue Untersuchungen..., s. 21-26, passim, oraz M. Reuther, Verfassung..., s. 82-83, na ich określenie użyli pojęcia villicationes; por. także R. Kötzschke, Vogtei..., s. 161, oraz wyżej, w ustępie o domniemanym włodarstwie zgorzeleckim.

125 Por. R. Kötzschke, Vogtei..., s. 161-162; K. Czok, Zur Entwicklung..., s. 110.

126 Władztwa już w XIII wieku wyróżniały się od innych lenn nie tylko rozmiarami i terytorialną zwartością, lecz także statusem prawnym: w świetle dokumentu potwierdzającego podział kraju między dwie linie Askańczyków z 1268 roku tylko ich dzierżyciele mieli bowiem otrzymywać inwestyturę z rąk władców obydwu części kraju, budziszyńskiej i zgorzeleckiej (CDLS I, 58). 
Drogą ${ }^{127}$. Dookoła każdego z królewskich miast powstał wieniec wsi lokacyjnych, co odzwierciedla znany doskonale z Połabia i Ślasska wzorzec systematycznej kolonizacji miejsko-wiejskiej. Na zastosowanie tego modelu w przypadku dość dobrze oświetlonego źródłowo Zgorzelca wskazuje zarówno czynny udział jego sołtysa Floryna w przedsięwzięciach kolonizacyjnych i wytyczaniu granic na obszarach wiejskich, jak i zaobserwowane przez Richarda Jechta pochodzenie wielu najstarszych zgorzeleckich rodzin patrycjuszowskich od zasadźców okolicznych wsi ${ }^{128}$. Można się zatem domyślać, że podobnie jak $w$ innych regionach owe okręgi otaczające królewskie miasta $-\mathrm{z}$ których dwa (Zgorzelca i Löbau) stały się zalążkami późniejszych dystryktów (weichbildów) - odgrywały pewną rolę w administracji i sądownictwie, $\mathrm{z}$ braku odpowiednich źródeł trudno jednak sprecyzować, jaka.

Bardzo interesująca odpowiedź na to pytanie zaproponowali J. Bauermann i R. Kötzschke, wskazując, że mimo braku na Górnych Łużycach wójtów okręgowych, w królewskich miastach mogły przecież odbywać się roki sądowe, na których budziszyński wójt krajowy rozsądzał sprawy z danego okręgu ${ }^{129}$. Według Bauermanna wystapienie na listach świadków dokumentów z lat 1234 i 1264, dotyczących wschodniej części kraju, obok wójtów krajowych także sołtysów zgorzeleckich sugeruje przy tym, że mogli oni działać jako ławnicy sądu ziemskiego (Landgericht, w znaczeniu sądu wójtowskiego, Vogtding). Koncepcja taka jest o tyle kusząca, że z zasiadania sołtysa zgorzeleckiego w sądzie ziemskim mogła wynikać jego kompetencja poza obszarem jurysdykcji miejskiej ${ }^{130}$. Niestety późniejsze źródła w najmniejszym nawet stopniu nie sugeruja, by zgorzelecki sołtys dziedziczny z urzędu stawał się ławnikiem sądu ziemskiego ${ }^{131}$. Przypadki możliwego wystapienia zgorzeleckich sołtysów w tej właśnie roli, przytoczone przez J. Bauermanna, mogą zatem wiązać się nie tyle z ich formalną pozycją, ile raczej z osobistym autorytetem tych osób należących do grona rycerstwa i zaangażowanych, jak było to widać na przykładzie zgorzeleckiego villici Floryna, także w sprawy wykraczające poza obszar miasta.

W poszukiwaniu źródeł jurysdykcji górnołużyckich sołtysów miejskich poza obszarami miast lokacyjnych warto powrócić do wskazanego powyżej zastosowania przez Przemyślidów nad Nysą i Sprewą sprawdzonego i typowego na początku XIII wieku modelu kolonizacji miejsko-wiejskiej. Jak wskazują współczesne akcji kolonizacyjnej

127 To samo można zresztą powiedzieć o Weissenbergu, który nie stał się jednak siedzibą archiprezbiteratu.

128 R. Jecht, Geschichte der Stadt Görlitz, s. 26. Podobną sytuację przenikania się elit miejskich i wiejskich w XIII i na początku XIV wieku można zaobserwować w dystrykcie namysłowskim na Śląsku; zob. M. Goliński, E. Kościk, J. Kęsik, Namysłów: Z dziejów miasta i okolic, Namysłów 2006, s. 32-35, $72-74,84$.

129 J. Bauermann, Die ältesten Urkunden..., s. 124; R. Kötzschke, Vogtei..., s. 168. Rozwiązanie takie było stosowane na terytoriach saskich i turyńskich, położonych na zachód od Górnych Łużyc, skąd płynęli do tego kraju osadnicy i wzorce organizacyjne; por. H. Eberhardt, Die Gerichtsorganisation..., s. 165, passim; W. Schlesinger, Zur Gerichtsverfassung..., s. 58, przyp. 6.

130 Por. interesującą rekonstrukcję rozwoju samodzielnych kompetencji sądowniczych sołtysów westfalskich w wyniku sądzenia przez nich w zastępstwie grafa poza trzema ,właściwymi” terminami (echte Ding, Dreiding): A. Hagemann, Von den mittelalterlichen Ständen Westfalens, ZRG GA 1952, Bd. 61, s. 337.

131 H. Knothe, Urkundliche Grundlagen..., s. 193, passim. Warto jednakże zastrzec, że w okresie lepiej oświetlonym źródłowo znaczenie zgorzeleckiego sołtysa dziedzicznego zmalało znacznie na rzecz ławy i rady miejskiej; zob. R. Jecht, Geschichte der Stadt Görlitz..., t. I/1, s. 47. 
na Górnych Łużycach przykłady śląskie ${ }^{132}$, organizacją kompleksowych przedsięwzięć lokacyjnych zajmowali się zasadźcy miast, którzy też z początku musieli sprawować pełną jurysdykcję w nowo założonych wsiach przynajmniej do czasu ukonstytuowania się w poszczególnych miejscowościach ich sołtysko-ławniczych sądów. Nawet jednak wówczas sołtys głównego miasta pozostawał przecież przedstawicielem pana terytorialnego, sprawował więc sądownictwo dominialne, dopóki i ta prerogatywa nie została mu odebrana w wyniku wypuszczenia poszczególnych miejscowości w lenno ${ }^{133}$. Wskazany już wyżej udział sołtysów (villici) Zgorzelca i Ostritz w kolonizacji wiejskiej sugeruje przy tym, że stosunki górnołużyckie nie odbiegały raczej w sposób znaczący od realiów śląskich ${ }^{134}$. Możliwe zatem, że wynikająca $\mathrm{z}$ dokumentów marienthalskich z lat 1238 -1239 jurysdykcja górnołużyckich villicorum poza obrębem miast stanowiła jedynie uprawnienie reliktowe wynikające $\mathrm{z}$ organizacji przez nich zasiedlenia poszczególnych dystryktów, rozpoczętego na większą skalę zaledwie kilkanaście lat przed wystawieniem przedmiotowych dyplomów. A może w ich rękach pozostały jakieś uprawnienia sądownicze, nieprzypisane sądom wiejskim, dominialnym i sądowi wójtowskiemu?

$\mathrm{W}$ poszukiwaniu odpowiedzi na to pytanie sięgnąc trzeba do źródeł $\mathrm{z}$ okresu rządów askańskich. W najstarszej zgorzeleckiej księdze miejskiej, tak zwanej Czerwonej Księdze, prowadzonej od 1305 roku, rzeczywiście sporadycznie pojawiają się zapiski niedotyczące mieszczan i nieruchomości miejskich ${ }^{135}$. Z pierwszych czterech lat prowadzenia księgi można przytoczyć cztery takie zapisy, z których pierwszy poświadcza legat dokonany przed sądem sołtysko-ławniczym Zgorzelca przez niejakiego Jana, syna sołtysa z Osieka Łużyckiego ${ }^{136}$. Charakter odnośnej czynności prawnej wskazuje, że podejmująca ją osoba dobrowolnie wybrała sąd miejski jako kompetentny w jej sprawie. Druga zapiska dotyczy natomiast wprawdzie działki położonej w Pfaffendorfie, więc poza obszarem jurysdykcji miejskiej, odnosi się jednak do sytuacji, w której mieszczanin zgorzelecki sprawował opiekę nad nieletnim właścicielem tej nieruchomości ${ }^{137}$. Dość jednoznaczna jest wzmianka trzecia, potwierdzająca zrzeczenie się przez niejakiego Mikołaja pretensji do mienia należącego do jego matki Kunny, wedle wszelkiego prawdopodobieństwa chłopki z Białogórza ${ }^{138}$. Kolejna interesująca zapiska dotyczy

132 Przede wszystkim przywilej biskupa Wawrzyńca dla wójta nyskiego Waltera z 1223 roku: SUB I, 225. Można tu także wskazać na przywileje dla Lwówka z 1217 roku i Nowogrodźca z 1233 roku, znane jednak z późniejszych odpisów, zapewne zawierających interpolacje. O uprawnieniach sądowniczych wójtów miast śląskich poza ich obrębem por. zbiorczo G.A. Tzschoppe, G.A. Stenzel, Geschichtliche Einleitung..., s. $182-183$.

133 Co na Górnych Łużycach, jak wskazano już wyżej, następowało zapewne niedługo po ich zasiedleniu.

134 Zdaje się jedynie, że Przemyślidzi jeszcze bardziej skrupulatnie niż Piastowie śląscy pilnowali swego monopolu na sądownictwo in maioribus, nie powierzając go nikomu sprawującemu urząd jako lenno dziedziczne (Erblehn).

135 Księga ta, zawierająca niemal wyłącznie legaty majątkowe dotyczące nieruchomości, dała początek prowadzonej później przez stulecia serii tzw. Libri resignationum.

136 Archiwum Państwowe we Wrocławiu, oddział w Lubaniu, zespół Akta Miasta Zgorzelca, nr 1, p. 4b: Johannes des shultheyzen sun vomme der windeshen ozzec hat gegeben siner husvrowen elsen virceg marg an sime gute zu eigene in gehetem dinge.

137 Ibidem, p. 9b: Nycolaus fursenf hat vorcoyft an sines stifkindes Nicolawes stat eine wise gelegen an der plesnitz, luten von phaffendorph umme zwenzigmark und die zwenzik marg sol daz selbe kint habbin an sime erbe. Wzmianka pochodzi z 1307 roku, a przedmiotem sprzedaży była łąka nad Pliessnitzbachem.

138 Ibidem, p. 11b: Kunna die vrowe von Lichtenberg hat sich berichtet mit Nyclawes irme sune, daz her sie nicht mer hindern sol an irme gute. Sformułowanie die vrowe von Lichtenberg wyraźnie ma służyć 
wprawdzie byłego sołtysa łagowskiego ${ }^{139}$, nie wynika z niej jednak niestety jasno ani że nie był on mieszczaninem zgorzeleckim ${ }^{140}$, ani że przedmiotowe dobra znajdowały się poza jurysdykcją miejska.

Wobec braku zapisek sądu ziemskiego, wójtowskiego (Landgericht), oraz przesłanek pozwalających stwierdzić, jaka część spraw niespornych przeprowadzanych przed sądem zgorzeleckiego wójta i ławników w ogóle doczekała się śladu w postaci wpisu do księgi, nie sposób niestety stwierdzić, czy zapisy dotyczące nieruchomości położonych poza jurysdykcją miejską dokonywane przed sądem miejskim były wówczas w okolicy Zgorzelca zjawiskiem normalnym, czy wyjątkowym. W odniesieniu do przytoczonych wzmianek nie da się także rozstrzygnąć, czy sięgający poza granice miasta autorytet zgorzeleckiego sądu wójtowsko-ławniczego w początku XIV wieku wiązał się z istnieniem jakichś jego dawnych kompetencji w tej mierze, czy wręcz przeciwnie, ze wzrostem znaczenia tego sądu związanym z reformą przeprowadzoną przez margrabiego Hermana w 1303 roku $^{141}$, bądź w ogóle wynikał z samego faktu prowadzenia w Zgorzelcu księgi sądowej, co nie było jeszcze w owym czasie praktykowane po okolicznych wsiach.

W poszukiwaniu zakresu i źródeł jurysdykcji zgorzeleckiego sołtysa (sędziego) dziedzicznego poza obszarem miejskim warto też zwrócić uwage na pewną praktykę, która znalazła odzwierciedlenie w statucie króla Jana Luksemburczyka z 22 maja 1329 roku. Dokument ów, zawierający rozstrzygnięcie sporu pomiędzy mieszczanami Zgorzelca a rycerstwem ziemi zgorzeleckiej, stanowił między innymi, że w sprawach o długi wobec mieszczan chłopi ziemi zgorzeleckiej, także ze wsi rycerskich, mieli być sądzeni przez zgorzelecki sąd miejski sołtysko-ławniczy. Wydaje się, że z treści dokumentu wynika, iż przedmiotem sporu mógł być tryb pozywania owych dłużników kondycji chłopskiej - z udziałem policyjnych uprawnień wójta, jeśli pozwany przebywał poza miastem i nie zamierzał się stawić przed oblicze sądu miejskiego - w żadnym jednak razie sama kompetencja zgorzeleckiego sądu miejskiego w tej mierze ${ }^{142}$. Nie ulega przy tym wątpliwości, że w statucie jest mowa nie o zreformowanym w 1303 roku sądzie wójtowskim, któremu in minoribus przewodniczyć miał dziedziczny sołtys zgorzelecki, lecz o sądzie miejskim, sołtysko-ławniczym. W związku z tym można wnosić, że kompetencja tego organu w odniesieniu do chłopów nie powstała w 1303 roku, lecz istniała niezależnie od przywilejów przyznanych zgorzelczanom przez Askańczyków ${ }^{143}$.

bliższemu określeniu osoby; gdyby chodziło o żonę bądź wdowę po mieszczaninie zgorzeleckim o przydomku von Lichtenberg, pisarz niechybnie wspomniałby także jego imię, jak czynił w innych zapiskach.

139 Ibidem, p. 11b: Eberhard der scultheyze war zcu Lutolfeshain hat gegeben siner husvrowen Gerdrude vunfzig Marg, an sime gute.

$140 \mathrm{O}$ ewentualności takiej nie należy zapominać; na tej samej stronie przedmiotowej księgi jest nawet wzmianka o prawdopodobnym przedstawicielu jednej z rozrodzonych rodzin zgorzeleckich mieszczan, zamieszkałym w Ludwigsdorfie (ibidem, p. 11b: Nycolawes suchworchte von Lodewigsdorph hat gegeben siner husvrowen Gerushen zwelf marg).

141 Por. R. Kötzschke, Vogtei..., s. 164.

142 CDLS I, 201: Darnach, ob ein burger beclagen wolde derselben unserer man [scil. rycerza trzymającego lenno w ziemi zgorzeleckiej] gepowren, ist daz derselbe gepowr chumpt in die stat oder in der stat gericht, der sol antwurten in der stat vor dem erbe richter und vor den vier benken, da der stat schepfen siczen und sol ir urteyl leiden.

143 Z braku źródeł pozostaje rzeczą niewiadoma, czy podobne uprawnienia względem chłopów posiadał także sołtys dziedziczny Löbau, jednak nie można tego wykluczyć, gdyż lakoniczność statutu z 1306 roku, na mocy którego nadano sołtysowi dziedzicznemu tego miasta jurysdykcję tam in maioribus, quam 
Przedstawiony wyżej przegląd możliwych kompetencji zgorzeleckiego sądu miejskiego poza obszarem samego miasta, ze względu na niedostatek źródeł, daleki jest od pełni. Pozwala jednak stwierdzić, że właściwość owej instytucji sądowej poza obszarem komunalnego miasta była ograniczona. Przede wszystkim nie obejmowała z pewnością sądownictwa wyższego oraz dotyczyła wyłącznie chłopów i sołtysów. Jurysdykcja sołtysa zgorzeleckiego mogła obejmować bliżej nieokreślony zakres spraw niespornych i tych, w których mieszczanin zgorzelecki był strona, przy czym z szerszą nieco kompetencją jego sądu można liczyć się w odniesieniu do okresu kolonizacji okolic miasta, w której mógł on sprawować funkcję kierowniczą. Główną instancją sądową dla mieszkańców ,ziemi” był jednak przez całe późne średniowiecze sąd sprawowany przez wójta krajowego ${ }^{144}$, i jeśli miasta górnołużyckie uzyskiwały szeroki wpływ na jurysdykcję poza swymi granicami, to odbywało się to przez nabycie przez nie landwójtostwa właśnie $^{145}$. Nie zmienia to faktu że, jak wskazano wyżej, istniał pewien zakres kompetencji sądowych in minoribus przysługujących miejskim sołtysom poza terytoriami objętymi prawem miejskim ${ }^{146}$, co mogło mieć niejaki wpływ na kształt formujących się w XIV wieku dystryktów - trzeba jednak z naciskiem podkreślić, że wpływ ów był z pewnością drugorzędny, gdyż pierwszoplanowe znaczenie dla powstania weichbildów miało przekazywanie miastom uprawnień landwójtowskich.

\section{Podsumowanie}

Wyniki przedstawionych powyżej rozważań można krótko podsumować następująco:

1) W źródłach nie ma dowodów na istnienie we wschodniej części Górnych Łużyc w okresie rządów Przemyślidów znaczniejszych kompleksów dóbr ziemskich zatrzymanych w bezpośredniej władzy królów i zarządzanych przez włodarzy, znane są natomiast przypadki zarządzania królewskimi dobrami przez monarszych wasali (włość zamkowa Landeskrone).

2) Analiza źródeł wskazuje, że znani z imienia górnołużyccy villici (Floryn ze Zgorzelca i Henryk z Ostritz) byli ściśle związani z lokacyjnymi miastami i najprawdopodobniej, zgodnie z sugestią Johannesa Bauermanna, należy ich utożsamić z sołtysami dziedzicznymi tychże.

3) Nie ma dowodów na istnienie na Górnych Łużycach domniemanych landwójtostw obdarzonych kompetencjami sądowniczymi in maioribus, źródła sugerują jednak sprawowanie pewnego (wąskiego) zakresu sądownictwa in minoribus poza obszarami jurysdykcji miast królewskich przez ich sołtysów (sędziów) dziedzicznych, co może świadczyć o dwojakiej genezie górnołużyckich dystryktów (weichbildów): opartych na sądownictwie wyższym i ziemskim (landwójtostwach) oraz niższym, sołtyskim.

\footnotetext{
in minoribus w okolicznych wsiach ziemi budziszyńskiej, nie pozwala rozstrzygnąć, czy jakiś zakres uprawnień sądu miejskiego w dystrykcie nie istniał aby już przed tą datą.

144 Por. H. Knothe, Urkundliche Grundlagen ..., s. 313-314.

145 Por. szczególnie casus Lubania: ibidem, s. 203-204.

$146 \mathrm{Z}$ dotychczas zajmujących się tym tematem autorów do najbardziej zbliżonych wyników doszedł W. Weizsäcker, Zur Geschichte..., s. 4.
} 